\title{
Trace metals in size-fractionated particulate matter in a Portuguese hospital: exposure risks assessment and comparisons with other countries
}

\author{
Klara Slezakova \& Simone Morais \& \\ Maria do Carmo Pereira
}

\begin{abstract}
Hospitals are considered as a special and important type of indoor public place where air quality has significant impacts on potential health outcomes. Information on indoor air quality of these environments, concerning exposures to partic- ulate matter (PM) and related toxicity, is limited though. This work aims to evaluate risks associated with inhalation exposure to ten toxic metals and chlorine (As, $\mathrm{Ni}, \mathrm{Cr}, \mathrm{Cd}, \mathrm{Pb}, \mathrm{Mn}, \mathrm{Se}, \mathrm{Ba}$, $\mathrm{Al}, \mathrm{Si}$, and $\mathrm{Cl})$ in coarse $\left(\mathrm{PM}_{2.5-10}\right)$ and fine $\left(\mathrm{PM}_{2.5}\right)$ particles in a Portuguese hospital in comparison with studies representative of other countries. Samples were collected during 1 month in one urban hospital; elemental PM characterization was determined by proton-induced X-ray emission. Noncarcinogenic and carcinogenic risks were assessed according to the methodology provided by the United States Environmental Protection Agency (USEPA; Region III Risk-Based Concentration Table) for three different age categories of hospital personnel (adults, $>20$, and $<65$ years) and patients (considering nine different age groups, i.e., children of $1-3$ years to seniors of $>65$ years). The estimated noncarcinogenic risks due to occupational inhalation exposure to $\mathrm{PM}_{2.5}$-bound metals ranged from $5.88 \times 10^{-6}$ for $\mathrm{Se}$ (adults, 55-64 years) to $9.35 \times 10^{-1}$ for As (adults, 20-24 years) with total noncarcinogenic risks (sum of all metals) above the safe level for all three age categories. $\mathrm{As}$ and $\mathrm{Cl}$ (the latter due to its high abundances) were the most important contributors (approximately $90 \%$ ) to noncarcinogenic risks. For $\mathrm{PM}_{2.5-10}$,
\end{abstract}

noncarcinogenic risks of all metals were acceptable to all age groups. Concerning carcinogenic risks, for $\mathrm{Ni}$ and $\mathrm{Pb}$, they were negligible $\left(<1 \times 10^{-6}\right)$ in both PM fractions for all age groups of hospital personnel; potential risks were observed for As and $\mathrm{Cr}$ with values in $\mathrm{PM}_{2.5}$ exceeding (up to 62 and 5 times, respectively) USEPA guideline across all age groups; for $\mathrm{PM}_{2.5-10}$, increased excess risks of As and $\mathrm{Cr}$ were observed particularly for long-term exposures (adults, 55-64 years). Total carcinogenic risks highly (up to 67 times) exceeded the recommended level for all age groups, thus clearly showing that occupational exposure to metals in fine particles pose significant risks. If the extensive working hours of hospital medical staff were considered, the respective noncarcinogenic and carcinogenic risks were increased, the latter for $\mathrm{PM}_{2.5}$ exceeding the USEPA cumulative guideline of $10^{-4}$. For adult patients, the estimated noncarcinogenic and carcinogenic risks were approximately three times higher than for personnel, with particular concerns observed for children and adolescents.

Keywords

Indoor air, PM, Risks, Metals, Hospital, Carcinogens

Introduction

There is growing public awareness regarding health risks associated with poor indoor air quality (Huboyo et al. 2011; Hulin et al. 2012; World Health Organization (WHO) 2010). Because people spend majority of their time indoors (Klepeis et al. 2001), they are at greater risk of adverse health effects from chronic exposures to indoor air pollutants (Bernstein et al. 2008). Among those concerns is exposure to inhalable particulate matter (PM). In recent years, scientific attention has focused mostly on fine fraction of particles $(<2.5 \mu \mathrm{m}$ in diameter; i.e., $\mathrm{PM}_{2.5}$; Brunekreef et al. 2009; Hoek et al. 2013; Li et al. 2013; Polichetti et al. 2009) that has been linked to 
both acute and chronic respiratory and cardiopulmonary health effects including lung cancer (Mitchell et al. 2007; Valavanidis et al. 2008). Additional focus has been placed on determining associations with PM components (elemental carbon, sulfates, nitrates, polycyclic aromatic hydrocarbons, and biological components; Atkinson et al. 2010; Brunekreef et al. 2009; Gent et al. 2009; Nemmar et al. 2013; Maynard et al. 2007; Sarnat et al. 2008). Although the precise mechanisms of PM health effects are not completely understood (Oeder et al. 2012), evidence has shown significant associations between PM properties (chemical and biological components, particle surface area, and reactivity) and its toxicity (Kelly and Fussell 2012; Nemmar et al. 2013). Therefore, PM chemical components may have high potential to contribute to PMinduced health effects (Schwarze et al. 2006) even though they compose only a small fraction of PM mass (Slezakova et al. 2007, 2009). Most studies of PM have focused on ambient (outdoor) exposures. The contribution and significance of indoor PM, which may differ substantially in composition from outdoor particulates, have yet to be fully explored.

PM composition is very complex. Previously, the risks of toxic compounds such polycyclic aromatic hydrocarbons in indoor and outdoor PM have been shown (Castro et al 2011; Slezakova et al. 2011a). Due to their toxic characters, trace metals are an important component of PM (Senlin et al. 2008). Some airborne trace metals may derive from natural crustal source, but the majority results from anthropogenic activities (Okuda et al. 2008) with main sources including (Fang et al. 2010; Susaya et al. 2010) vehicle emissions (primary source for chromium, lead cadmium, and barium), industrial and construction processes (responsible for manganese, aluminum, and silicon), oil (responsible for nickel) and coal combustions (chromium), and metal industry (metal specific). In indoor environments, the abundance of the trace elements results from infiltration of outdoor emissions (Habil et al. 2013; Hassan 2012) and from various indoor sources which include different wall paints and indoor equipment and utensils (Chattopadhyay et al. 2003; Kebede et al. 2013; Paoletti et al. 2006; Taner et al. 2013). Most trace metals exist in the solid phase and thus occur almost exclusively in the particle phase of the atmosphere, where they are ubiquitous in both fine and coarse fractions (Hu et al. 2012; Singh et al. 2011). For health risks assessment, size distributions of atmospheric trace metals and other elements is significant (Kelly and Fussell 2012). Whereas metals from crustal sources tend to accumulate in coarse mode of particles (i.e., those larger than approximately 1-3 $\mu \mathrm{m}$; (Lü et al. 2012; Slezakova et al. 2008), the more toxic metals from anthropogenic sources are predominantly found in the fine fraction of atmospheric particles (Chen and Lippmann 2009; Song and Gao 2011; Greene and Morris 2006). In small quantities they might be harmless, but many of the trace metals (and metallic compounds) are harmful to humans (WHO 2007). According to the
International Agency for Research on Cancer(IARC), arsenic, cadmium, and hexavalent chromium and nickel compounds are classified as carcinogenic to humans (IARC Working Group on the Evaluation of Carcinogenic Risks to Humans 2012) whereas inorganic lead compounds are classified as probable carcinogens (IARC Working Group on the Evaluation of Carcinogenic Risks to Humans 2006). Accumulation in fatty tissues and circulatory system, negative effects on central nervous system, and functioning of internal organs as well as acting as cofactors in other diseases and cancer are some of the negative health effects associated with exposure to these metals (Chen and Lippmann 2009; KurtKarakus 2012). Therefore, in order to protect public health, the European Union Directive 2004/107/EC (2005) settled limits of atmospheric metals considering three carcinogenic metals (arsenic, nickel, and cadmium) in ambient air. As these elements represent hazard to human health, careful monitoring should be considered. Furthermore, the investigation of the health risks associated with airborne metals may provide useful information regarding environmental risks of indoor environments.

Hospitals are considered as a special and important type of indoor public place (Banse 2013; Barnett and Barnett 2003) where poor air quality can affect not only the health of the employees but also of patients (due to suppressed immune system, they are more susceptible to external influences). Assessment of risks to these occupants resulting from exposure to airborne particulates includes measurements of PM concentration levels and their related toxicity in terms of trace metals (or ions). However, information concerning PM levels in hospitals is limited (and non-existent in Portugal). Additionally, there is a lack of knowledge on PM trace metals in these environments (Brown et al. 2012; Wang et al. 2006a) and the associated health impacts. Considering the importance of the hospital to public health, further studies are necessary in order to fully assess the risks of particulate exposures and related toxicity in the respective environments. The aim of this study was to estimate the risks associated with exposure to particulate-bound trace metals in the hospital environment. Hospital staff and patients were considered as the exposed groups. The concentrations of trace elements, namely aluminum $(\mathrm{Al})$, silicon $(\mathrm{Si})$, chlorine $(\mathrm{Cl})$, manganese $(\mathrm{Mn})$, selenium $(\mathrm{Se})$, barium $(\mathrm{Ba})$, arsenic (As), lead $(\mathrm{Pb})$, cadmium $(\mathrm{Cd})$, chromium $(\mathrm{Cr})$, and nickel $(\mathrm{Ni})$ collected in Portuguese hospital were determined in indoor coarse $\left(\mathrm{PM}_{2.5-10}\right)$ and fine $\left(\mathrm{PM}_{2.5}\right)$ particles. The specific objectives of this work were (a) to evaluate noncarcinogenic risks associated with inhalation exposure to 11 potentially toxic trace elements in $\mathrm{PM}_{2.5-10}$ and $\mathrm{PM}_{2.5}$; (2) to evaluate carcinogenic risks from inhalation exposure to fine particles and to $\mathrm{PM}_{2.5-10}$ and $\mathrm{PM}_{2.5}$-bound metals; and (3) to assess and compare PM indoor air quality in a Portuguese urban hospital with studies representative of other countries and existing guidelines. 

Materials and methods

Sample collection

Particulates were collected for a period of 4 weeks in the hospital of Vila Nova de Gaia, which belongs to the Metropolitan Area of Oporto (NW region of Portugal) and corresponds to the second largest municipality in Portugal. The hospital complex is surrounded by national roads and is located in the direct vicinity of the busiest highway in Portugal that connects the north and south of the country (Fig. 1); the highway is also the main road connection to the north of Spain. Consequently, emissions from road traffic are the main source of atmospheric pollutants in the respective area. Samples were collected daily for a period of $24 \mathrm{~h} \mathrm{(7:30} \mathrm{a.m.} \mathrm{to}$ 7:30 a.m. of the next day) by constant flow samplers (Bravo H2, TCR TECORA, Italy) that were combined with PM EN LVS sampling heads (in compliance with norm EN12341 for $\mathrm{PM}_{10}$ and EN14907 for $\mathrm{PM}_{2.5}$ ); an air flow rate of $2.3 \mathrm{~m}^{3} \mathrm{~h}^{-1}$ was used. The sampling apparatuses were positioned inside a main corridor of the radiology ward that was designated to both children (older than 1 year) and adult patients. Inlets were

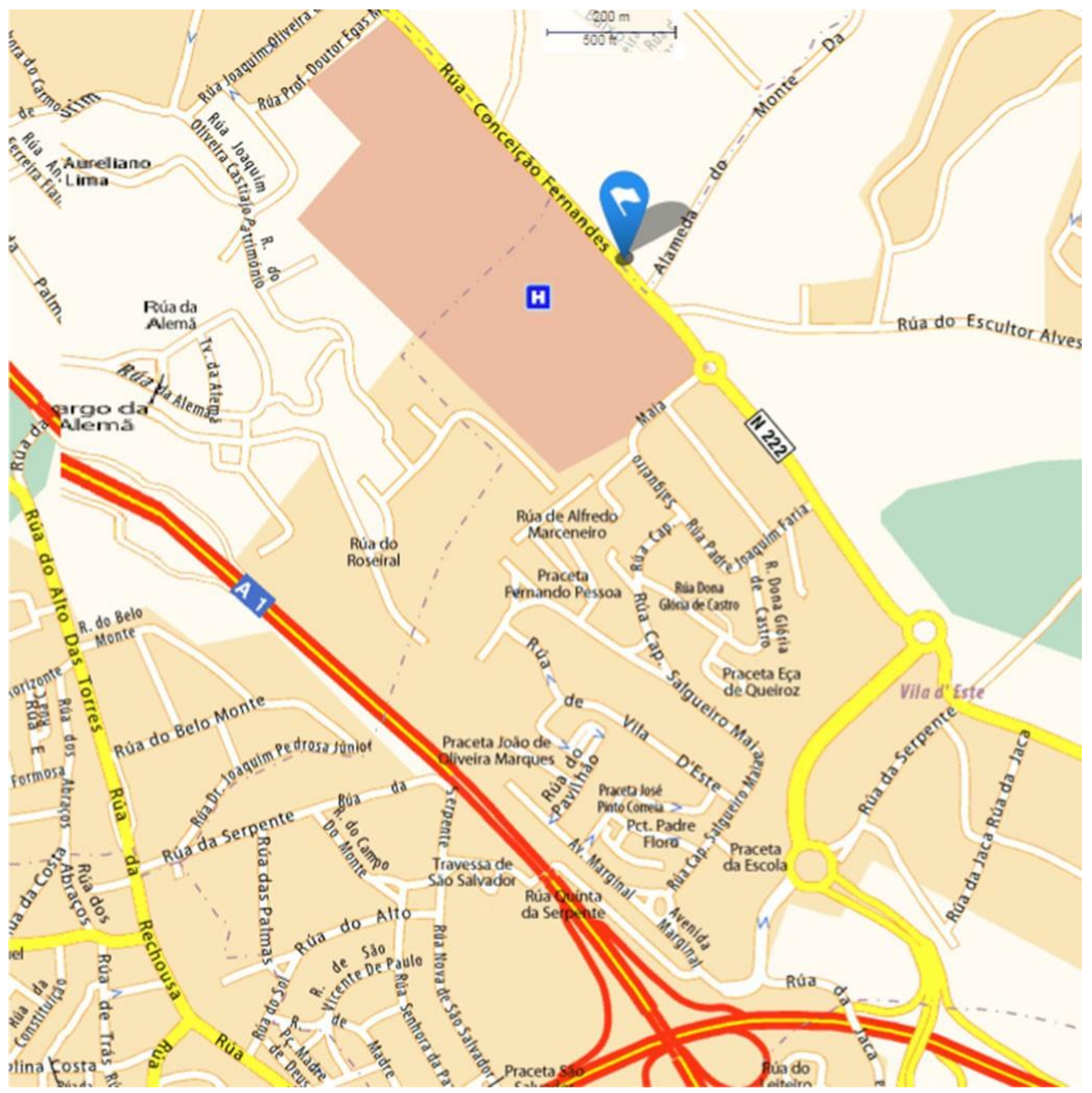

Fig. 1 Location of the studied hospital 
placed $1.6 \mathrm{~m}$ above the floor (in order to simulate human breathing zone) and minimally $1 \mathrm{~m}$ from the walls, without obstructing the normal usage of the rooms. PM masses were collected on polytetrafluoroethylene (PTFE) membrane filters with polymethylpentene support ring $(2 \mu \mathrm{m}$ pore size, $\varnothing 47 \mathrm{~mm}$; SKC Ltd, UK). During the monitoring period, a detailed record was kept on the activities in the area surrounding the sample collection. Concerning PM indoor sources, no significant differences were observed between the activities performed by the personnel; smoking was prohibited in all areas of the hospital.

PM mass determination

$\mathrm{PM}_{10}$ and $\mathrm{PM}_{2.5}$ masses were determined gravimetrically as described previously in detail in Slezakova et al. (2009). Briefly, the initial mean mass of the blank filter was subtracted from the final mean mass of the exposed filter; the difference was then divided by the total volume of air that passed through filter (at $25^{\circ} \mathrm{C}$ and $101.3 \mathrm{kPa}$ ). $\mathrm{PM}_{2.5-10}$ fraction (i.e., coarse fraction with particles of aerodynamic diameter between 2.5 and $10 \mu \mathrm{m}$ ) was determined as difference (by subtraction) between $\mathrm{PM}_{10}$ and $\mathrm{PM}_{2.5}$.

\section{Elemental characterization}

Elemental characterization of $\mathrm{PM}_{10}$ and $\mathrm{PM}_{2.5}$ was performed by proton-induced X-ray emission (PIXE), which provided analysis for elements from magnesium trough uranium. For elemental analysis, PTFE filters were cut in half. One half of the filter was analyzed, whereas the other part was kept for possible replicates and other analysis. PIXE analyses were carried out at a Van de Graaff accelerator, in vacuum. For each of the samples, two X-ray spectrum were taken; one with a 1.2 $\mathrm{MeV}$ proton beam and no absorber in front of the $\mathrm{Si}(\mathrm{Li})$ detector for low energy X-ray elements, and another with a $2.25 \mathrm{MeV}$ proton beam and a $250 \mathrm{~mm}$ Mylarß filter to detect elements with atomic number higher than 20 . The beam area at the target was $20 \mathrm{~mm}^{2}$. Spectra deconvolution was performed with the AXIL computer code V3.0 and quantitative analysis was carried out with the DATTPIXE package (Almeida et al. 2003; Freitas et al. 2003).

Health risk analysis

Noncarcinogenic and carcinogenic risks were assessed according to the methodology provided by the USEPA Region III Risk-Based Concentration Table (United States Environmental Protection Agency (USEPA) 2013a). The noncarcinogenic risks of each individual metal were assessed by the noncancer hazard quotient (THQ; USEPA 1989): "the ratio of a single substance exposure level over a specified time period (e.g., subchronic) to a reference dose (RfD) for that substance derived from a similar exposure period". THQ assumes that there is a level of exposure (i.e., RfD) below which it is unlikely for even sensitive populations to experience adverse health effects. If the exposure level (E) exceeds this threshold (i.e., if $\mathrm{E} / \mathrm{RfD}$ exceeds unity), there may be concern for potential noncancer effects (USEPA 1989); higher values of THQ (above unity) indicate the greater levels of concern.

The carcinogenic risks were assessed as the incremental probability of an individual to develop cancer, over a lifetime, as a result of exposure to that potential carcinogen (i.e., incremental or excess individual lifetime cancer risk; USEPA 1989). Acceptable risk levels for carcinogens range from $10^{-4}$ (risk of developing cancer over a human lifetime is 1 in 10 , 000 ) to $10^{-6}$ (risk of developing cancer over a human lifetime is 1 in 1,000,000).

The following equations were used to calculate noncarcinogenic and carcinogenic risks associated with inhalation exposure to trace elements in indoor environment:

$$
\mathrm{THQ}=(\mathrm{EFr} \times \mathrm{ED} \times \mathrm{ET} \times C \times \mathrm{IR}) /(\mathrm{RfD} \times \mathrm{BW} \times \mathrm{AT})
$$

$$
\mathrm{TR}=(\mathrm{EFr} \times \mathrm{ED} \times \mathrm{ET} \times \mathrm{C} \times \mathrm{IUR}) /(\mathrm{AT})
$$

where THQ and target carcinogenic risk (TR) are dimensionless, EFr is the exposure frequency ( 250 days per year; USEPA 2013a), ED is the exposure duration (years), ET is the exposure time ( $8 \mathrm{~h}$ per day for hospital personnel and $24 \mathrm{~h}$ per day for patients; USEPA 2013a), $C$ is the concentration of metal in air $\left(\mathrm{mg} \mathrm{m}^{-3}\right)$, IR is the inhalation rate $\left(\mathrm{m}^{3} \mathrm{day}^{-1}\right)$, BW is the body weight $(\mathrm{kg})$, AT is the number of days over which the exposure is averaged ( 365 days per year $\times \mathrm{ED}$ for noncarcinogenic effects and 25,500 days, i.e., 70 years $\times 365$ days per year for carcinogenic effects; USEPA 2013a), RfD is the inhalation reference dose $\left(\mathrm{mg} \mathrm{kg}^{-1} \mathrm{day}^{-1}\right)$, and IUR is the chronic inhalation unit risk $\left(\mu \mathrm{g} \mathrm{m}^{-3}\right.$; USEPA 2013a). Since RfD values are only available for oral exposure (USEPA 2013a), the RfD values were converted from existent USEPA reference concentrations for inhalation exposure according to the USEPA(2013b):

$$
\mathrm{RfD}=\left(\mathrm{RfC} \times \mathrm{IR}_{A} \times \mathrm{AR}\right) /\left(\mathrm{BW}_{A} \times 100\right)
$$

where $\mathrm{RfC}$ is the reference concentration $\left(\mathrm{mg} \mathrm{m}^{-3}\right), \mathrm{IR}_{A}$ and $\mathrm{BW}_{A}$ are the inhalation rate and body weight of an adult $\left(20 \mathrm{~m}^{3} \mathrm{day}^{-1}\right.$ and $70 \mathrm{~kg}$; USEPA 2013b), and AR is the absorption rate (100\%; USEPA 2013b). The converted RfD values are presented in Table 1. Noncarcinogenic risks were estimated for nine trace elements for which RfC values (in brackets) are available (USEPA 2013a): aluminum $(5 \times$ $\left.10^{-3} \mathrm{mg} \mathrm{m}^{-3}\right)$, silicon $\left(3 \times 10^{-3} \mathrm{mg} \mathrm{m}^{-3}\right)$, chlorine $(1.5 \times$ 
$\left.10^{-4} \mathrm{mg} \mathrm{m}^{-3}\right)$, manganese $\left(5 \times 10^{-5} \mathrm{mg} \mathrm{m}^{-3}\right)$, selenium $(2 \times$ $\left.10^{-2} \mathrm{mg} \mathrm{m}^{-3}\right)$, barium $\left(5 \times 10^{-4} \mathrm{mg} \mathrm{m}^{-3}\right)$, hexavalent chromium-Cr(VI) $\left(1 \times 10^{-4} \mathrm{mg} \mathrm{m}^{-3}\right)$, nickel-refinery dust $(5 \times$ $\left.10^{-5} \mathrm{mg} \mathrm{m}^{-3}\right)$, and arsenic-inorganic $\left(1.5 \times 10^{-5} \mathrm{mg} \mathrm{m}^{-3}\right)$.

Similarly when available, the IUR values were retrieved for four carcinogenic elements (possible probable) as the follow-

ing ( USEPA 2013a): nickel (refinery dust; $4.8 \times 10^{-4}(\mu \mathrm{g}$ $\left.\left.\mathrm{m}^{-3}\right)^{-1}\right)$, arsenic (inorganic; $\left.4.3 \times 10^{-3}\left(\mu \mathrm{g} \mathrm{m}^{-3}\right)^{-1}\right)$, lead (acetate; $\left.1.2 \times 10^{-5}\left(\mu \mathrm{g} \mathrm{m}^{-3}\right)^{-1}\right)$, and hexavalent chromi- um $\left(8.4 \times 10^{-2}\left(\mu \mathrm{g} \mathrm{m}^{-3}\right)^{-1}\right)$. In this work, hospital staff and

patients were considered as the exposed populations. Hospital staff was represented only by adults (i.e., older than 20 years and $<65$ years). Three different age categories of adults were considered, namely 20-24, 25-54, and 55-64 years (USEPA 2011). Nine different age categories of patients ranging from children of 1 year to seniors $>65$ years were used for the estimation of target risks (Vieira et al. 2011; USEPA 2011) with the following ED values (in brackets): children $1-3$ years ( 1 year), children 4-6 years (4 years), children 7-10 years (7 years), adolescents 11-14 years (11 years), adolescents 1519 years ( 15 years), adults $20-24$ years ( 20 years), adults $25-$ 54 years ( 25 years), adults 55-64 years ( 55 years), and seniors $>65$ years (65 years) (USEPA 2011). Body weights and inhalation rates for the respective age categories were adapted from USEPA (2011) as the following: children 1-3 years $\left(14 \mathrm{~kg} ; 8.5 \mathrm{~m}^{3}\right.$ day $\left.^{-1}\right)$, children $4-6$ years $(21 \mathrm{~kg}$; $10.1 \mathrm{~m}^{3}$ day $\left.^{-1}\right)$, children $7-10$ years $\left(32 \mathrm{~kg} ; 12.0 \mathrm{~m}^{3}\right.$ day $\left.^{-1}\right)$, adolescents $11-14$ years $\left(51 \mathrm{~kg} ; 15.2 \mathrm{~m}^{3} \mathrm{day}^{-1}\right)$, adolescents $15-19$ years $\left(67 \mathrm{~kg} ; 16.3 \mathrm{~m}^{3}\right.$ day $\left.^{-1}\right)$, adults $20-24$ years $\left(72 \mathrm{~kg} ; 15.7 \mathrm{~m}^{3} \mathrm{day}^{-1}\right)$, adults $25-54$ years $(77 \mathrm{~kg}$; $15.9 \mathrm{~m}^{3}$ day $\left.^{-1}\right)$, adults $55-64$ years $\left(77 \mathrm{~kg} ; 14.9 \mathrm{~m}^{3}\right.$ day $\left.^{-1}\right)$, and seniors $>65$ years $\left(72 \mathrm{~kg} ; 13.4 \mathrm{~m}^{3}\right.$ day $\left.^{-1}\right)$.

Statistical analysis

For data treatment, the Student's $t$ test was applied to determine the statistical significance ( $p<0.05$, two tailed) of the differences between the determined means.

\section{Results and discussion}

\section{PM concentrations}

In the studied hospital, 24-h $\mathrm{PM}_{10}$ concentrations ranged between 13 and $59 \mu \mathrm{g} \mathrm{m}^{-3}$ with a median value of $38 \mathrm{\mu g} \mathrm{m}^{-3}$. On average, $77 \%$ of indoor $\mathrm{PM}_{10}$ was composed of $\mathrm{PM}_{2.5}$ (range of 11-42 $\mathrm{g} \mathrm{m} \mathrm{m}^{-3}$; median of $30 \mu \mathrm{g} \mathrm{m}^{-3}$ ). Coarse (i.e., $\mathrm{PM}_{2.5-10}$ ) particles ranged between 2.5 and $22 \mathrm{\mu g} \mathrm{m}^{-3}$ (median of $6 \mathrm{\mu g} \mathrm{m}^{-3}$ ), and they accounted for $23 \%$ of indoor PM. Furthermore, statistical analysis of the results indicated that $\mathrm{PM}_{2.5-10}$ mean $\left(7.4 \pm 4.1 \mu \mathrm{g} \mathrm{m}^{-3}\right)$ was significantly lower $(p<0.05)$ than $\mathrm{PM}_{2.5}\left(23 \pm 10 \mu \mathrm{g} \mathrm{m} \mathrm{m}^{-3}\right)$.
Table 1 RfD values of ten elements

\begin{tabular}{lll}
\hline Metal & RfC $\left(\mathrm{mg} \mathrm{m}^{-3}\right)$ & RfD $\left(\mathrm{mg} \mathrm{kg}^{-1}\right.$ day $\left.^{-1}\right)$ \\
\hline $\mathrm{Al}$ & $5.00 \times 10^{-3}$ & $1.43 \times 10^{-3}$ \\
$\mathrm{Si}$ & $3.00 \times 10^{-3}$ & $8.57 \times 10^{-4}$ \\
$\mathrm{Cl}$ & $1.50 \times 10^{-4}$ & $4.29 \times 10^{-5}$ \\
$\mathrm{Mn}$ & $5.00 \times 10^{-5}$ & $1.43 \times 10^{-5}$ \\
$\mathrm{Se}$ & $2.00 \times 10^{-2}$ & $5.71 \times 10^{-3}$ \\
$\mathrm{Ba}$ & $5.00 \times 10^{-4}$ & $1.43 \times 10^{-4}$ \\
$\mathrm{Cr}$ & $1.00 \times 10^{-4}$ & $2.86 \times 10^{-5}$ \\
$\mathrm{Ni}$ & $5.00 \times 10^{-5}$ & $1.43 \times 10^{-5}$ \\
$\mathrm{As}$ & $1.50 \times 10^{-5}$ & $4.29 \times 10^{-6}$ \\
$\mathrm{Cd}$ & $2.00 \times 10^{-5}$ & $5.71 \times 10^{-6}$ \\
\hline
\end{tabular}

Overall, obtained $\mathrm{PM}_{10}$ and $\mathrm{PM}_{2.5}$ were in similar ranges as in nonsmoking residences (Minguillón et al. 2012; Slezakova et al. 2009, 2011b) but lower (approximately three to ten times) than in public places (restaurants, supermarkets, and commercials offices) or schools (Dong et al. 2013; Habil et al. 2013; Taner et al. 2013). All existent studies dedicated to PM in hospitals are summarized in Table 2. Concerning Europe, available information on PM in hospitals exists only for fine fraction (Fernández et al. 2009; Nardini et al. 2004; Sureda et al. 2010). $\mathrm{PM}_{2.5}$ levels obtained in the Portuguese hospital were significantly higher $(p<0.05)$ than those found in other European countries. All European studies referred in Table 2 were performed in order to assess environmental tobacco smoke; $\mathrm{PM}_{2.5}$ was used as its marker. Therefore, different organization of these studies, very different sampling protocols with limited period of sample collections may account for some of the observed differences in PM levels. More information on both $\mathrm{PM}_{10}$ and $\mathrm{PM}_{2.5}$ comes from Asian countries (Table 2). Two studies performed in Taiwan reported similar concentration ranges of $\mathrm{PM}_{10}$ (Wan et al. 2011) and $\mathrm{PM}_{2.5}$ (Hsu et al. 2012) to those in Portugal. In India and China, observed $\mathrm{PM}_{2.5}$ and $\mathrm{PM}_{10}$ in hospital environments were much higher than in Portugal (three to four times; Verma and Taneja 2011; Wang et al. 2006a, b). These findings are not so surprising considering the typically much higher levels of ambient air pollution in Asian countries. Despite the higher levels, Wang et al. (2006a, b) who investigated PM levels in four different Chinese urban hospitals reported mean $\mathrm{PM}_{2.5} /$ $\mathrm{PM}_{10}$ ratio of 0.78 ; a similar mean of 0.77 was observed in this study. Fine particles thus constituted a major fraction of $\mathrm{PM}_{10}$ in the studied hospital. These findings are health relevant because especially $\mathrm{PM}_{2.5}$ represents a serious risk to human health; when inhaled, these particles may reach the peripheral regions of the bronchioles and interfere with gas exchange inside the lungs (WHO 2000). Nevertheless, the current Portuguese legislation for indoor air quality Decreto Lei 79/2006 (2006) provides limits only for $\mathrm{PM}_{10}$ fraction (defined as 
Table 2 Comparison of $\mathrm{PM}_{2.5}$ and $\mathrm{PM}_{10}$ in hospitals: summary of existing studies

\begin{tabular}{|c|c|c|c|c|c|}
\hline Country & Fraction & Mean $(\min -\max )\left(\mu \mathrm{g} \mathrm{m}^{-3}\right)$ & Study organization & Sampling protocol & Reference \\
\hline Portugal & $\begin{array}{l}\mathrm{PM}_{10} \\
\mathrm{PM}_{2.5} \\
\mathrm{PM}_{2.5-10}\end{array}$ & $\begin{array}{l}31(13-59) \\
23(11-42) \\
7.4(2.5-22)\end{array}$ & 1 hospital & $\begin{array}{l}\text { 24-h PM mass samples; } \\
\text { collected during } 28 \text { days; } \\
\text { constant flow }\left(38.6 \mathrm{~L} \mathrm{~min}^{-1}\right)\end{array}$ & This study \\
\hline Taiwan & $\begin{array}{l}\mathrm{PM}_{10} \\
\mathrm{PM}_{2.5}\end{array}$ & $\begin{array}{l}\text { n.r. }(22-90) \\
\text { n.r. }(5-35)\end{array}$ & $\begin{array}{l}8 \text { hospitals; IAQ study } \\
\text { of } 39 \text { public places; }\end{array}$ & $\begin{array}{l}\text { 2-min (phase } 1 \text { ) and } 24-\mathrm{h} \text { (phase } 2 \text { ) } \\
\text { PM collection; } \beta \text {-ray decay method }\end{array}$ & Hsu et al. (2012) \\
\hline Taiwan & $\mathrm{PM}_{2}$ & $\begin{array}{l}\text { n.r. }(0.8-55.6) \\
\text { Transplantation room: } \\
\quad 10.7(1.3-37.8) \\
\text { Trauma room: } 5.6 \\
\quad(3.2-55.6) \\
\text { Cardiovascular surgery room: } \\
\quad 3.0 \text { (0.8-7.8) } \\
\text { Colon surgery room: } 10.0 \\
\quad(1.6-49.1) \\
\text { Orthopedic surgery room: } \\
\quad 12.6(3.3-31.2) \\
\text { n.r. }(0.1-8.4) \\
\text { Transplantation room: } \\
0.9 \text { (0.2-3.1) } \\
\text { Trauma room: } \\
\quad 1.1(0.5-8.4) \\
\text { Cardiovascular room: } \\
0.3 \text { (0.1-0.7) } \\
\text { Colon surgery room: } \\
0.8 \text { (0.3-2.6) } \\
\text { Orthopedic room: } \\
0.9 \text { (0.4-7.5) }\end{array}$ & $\begin{array}{r}1 \text { hospital; various } \\
\text { operating rooms }\end{array}$ & $\begin{array}{l}\text { PM mass concentrations during } 60 \mathrm{~min} \text {; } \\
\text { weakly sampling for } 8 \text { consecutive } \\
\text { months; light-scattering aerosol } \\
\text { analyzer; constant flow }\left(1.2 \mathrm{~L} \mathrm{~min}^{-1}\right)\end{array}$ & Wan et al. (2011) \\
\hline Taiwan & $\begin{array}{l}\mathrm{PM}_{10} \\
\mathrm{PM}_{2.5}\end{array}$ & $\begin{array}{l}\text { n.r. (n.r.) } \\
\text { n.r. (n.r.) }\end{array}$ & $\begin{array}{l}6 \text { hospitals; IAQ study } \\
\text { of } 21 \text { public places }\end{array}$ & $\begin{array}{l}\text { Walk-through 2-min samples and } \\
\text { during 24-h; } \beta \text {-ray decay method }\end{array}$ & Wang et al. (2011) \\
\hline China & $\begin{array}{l}\mathrm{PM}_{10} \\
\mathrm{PM}_{2.5}\end{array}$ & $\begin{array}{l}128.13(61.67-250.00) \\
99.06(40.94-214.91)\end{array}$ & 4 hospitals & $\begin{array}{l}\text { 24-h PM mass samples collected } \\
\text { during total of } 32 \text { days; low flow } \\
\text { samples }\left(5 \mathrm{~L} \mathrm{~min}^{-1}\right)\end{array}$ & $\begin{array}{l}\text { Wang et al. } \\
\qquad(2006 \mathrm{a}, \mathrm{b})\end{array}$ \\
\hline India & $\begin{array}{l}\mathrm{PM}_{10} \\
\mathrm{PM}_{2.5}\end{array}$ & $\begin{array}{l}136.36-316.11(73.38-441.79) \\
67.28-95.70 \\
\quad(39.55-146.25)\end{array}$ & 5 hospitals & $\begin{array}{l}\text { 1-2 } \mathrm{h} \text { continuous } \mathrm{PM} \text { concentration } \\
\text { measurements; light-scattering } \\
\text { aerosol analyzer; constant flow } \\
\left(1.2 \mathrm{~L} \mathrm{~min}^{-1}\right)\end{array}$ & $\begin{array}{l}\text { Verma and Taneja } \\
\text { (2011) }\end{array}$ \\
\hline Turkey & $\mathrm{PM}_{2.5}$ & $\begin{array}{l}\text { Geriatrics: } 18.1 \pm 4.5(8.9-23.1) \\
\text { Nephrology: } 23.4 \pm 3.3 \\
\quad(16.4-31.4) \\
\text { Cardiology: } 37.9 \pm 13.3 \\
\quad(18.3-58.5)\end{array}$ & $\begin{array}{l}\text { Assessment of } 1 \text { medical } \\
\text { faculty including its hospital } \\
\text { and some clinics }\end{array}$ & $\begin{array}{l}\text { 8-h continuous PM concentration } \\
\text { measurements during total of } 26 \\
\text { workdays; light scattering sensing } \\
\text { monitor; logging interval } 15 \mathrm{~s} ; \\
\text { constant flow rate }\end{array}$ & Yurtseven et al. (2012) \\
\hline USA & & n.r. $(\sim 2-8)^{\mathrm{a}}$ & $\begin{array}{l}\text { Residential and non-residential } \\
\text { indoor micro-environments; } \\
1 \text { hospital }\end{array}$ & $\begin{array}{l}7 \text { consecutive days in } 2 \text { seasons; } \\
\text { 24-h PM mass samples and } \\
\text { continuous PM concentrations } \\
\text { measurements }\end{array}$ & Brown et al. (2012) \\
\hline Italy & $\mathrm{PM}_{2.5}$ & $\begin{array}{l}\text { Operating room: } \\
\quad 1.6 \pm 0.9 \text { (n.r.) } \\
\text { Waiting room: } 12.9 \pm 1.1 \text { (n.r.) } \\
\text { Medical office: } 14.8 \pm 2.2 \text { (n.r.) }\end{array}$ & $\begin{array}{l}2 \text { hospitals; } \mathrm{PM}_{2.5} \text { assessed as } \\
\text { marker for } \mathrm{ETS}^{\mathrm{b}}\end{array}$ & $\begin{array}{l}\text { 10-h continuous concentration } \\
\text { measurements in various hospital } \\
\text { areas; laser-operated aerosol mass } \\
\text { analyzer; logging interval } 2 \text { min }\end{array}$ & Nardini et al. (2004) \\
\hline Spain & $\mathrm{PM}_{2.5}$ & $\begin{array}{l}17.94 \text { (n.r.) } \\
\text { Dressing rooms: } 8.92 \text { (n.r.) } \\
\text { Fire escapes: } 34.43 \text { (n.r.) } \\
\text { Emergency department room: } \\
\quad 16.11 \text { (n.r.) } \\
\text { Hall: } 18.90 \text { (n.r.) } \\
\text { General medicine : } 12.46 \text { (n.r.) } \\
\text { Cafeteria: } 17.59 \text { (n.r.) }\end{array}$ & $\begin{array}{l}53 \text { hospitals; } \mathrm{PM}_{2.5} \text { assessed as } \\
\text { marker for ETS; sample } \\
\text { collection for } 15 \mathrm{~min}\end{array}$ & $\begin{array}{l}\text { 15-min } \mathrm{PM}_{2.5} \text { concentration samples } \\
\text { at each location; light scattering } \\
\text { aerosol monitor; constant flow } \\
\left(1.7 \mathrm{~L} \mathrm{~min}^{-1}\right)\end{array}$ & Sureda et al. (2010) \\
\hline
\end{tabular}


Table 2 (continued)

\begin{tabular}{|c|c|c|c|c|c|}
\hline Country & Fraction & Mean $(\min -\max )\left(\mu \mathrm{g} \mathrm{m}^{-3}\right)$ & Study organization & Sampling protocol & Reference \\
\hline & & Main entrance: 19.26 (n.r.) & \multirow{6}{*}{$\begin{array}{l}30 \text { hospitals in } 7 \text { European } \\
\text { countries; } \mathrm{PM}_{2.5} \text { assessed as } \\
\text { marker for ETS; } 8 \text { observed } \\
\text { sublocations: hall/main } \\
\text { entrance, emergency }\end{array}$} & \multirow{9}{*}{$\begin{array}{l}\text { 2-min PM mass concentrations at } \\
\text { each sublocation; all hospitals } \\
\text { sampled within 1-2 weeks; light } \\
\text { scattering sensing monitor }\end{array}$} & \multirow{9}{*}{ Fernández et al. (2009) } \\
\hline & & Smoking area: 27.32 (n.r.) & & & \\
\hline Austria & $\mathrm{PM}_{2.5}$ & $3.00^{\mathrm{c}}$ (n.r.) & & & \\
\hline Belgium & $\mathrm{PM}_{2.5}$ & $3.0^{\mathrm{c}}$ (n.r.) & & & \\
\hline France & $\mathrm{PM}_{2.5}$ & $3.5^{\mathrm{c}}$ (n.r.) & & & \\
\hline Germany & $\mathrm{PM}_{2.5}$ & $1.5^{\mathrm{c}}$ (n.r.) & & & \\
\hline Greece & $\mathrm{PM}_{2.5}$ & $4.0^{\mathrm{c}}$ (n.r.) & department waiting & & \\
\hline Romania & $\mathrm{PM}_{2.5}$ & $10.0^{\mathrm{c}}$ (n.r.) & room, internal medicine & & \\
\hline Spain & $\mathrm{PM}_{2.5}$ & $5.0^{\mathrm{c}}$ (n.r.) & $\begin{array}{l}\text { hospitalization unit, cafeteria, } \\
\text { fire escape, general surgery, } \\
\text { smoking areas (when existent), } \\
\text { and other places }\end{array}$ & & \\
\hline
\end{tabular}

n.r. not reported, $I A Q$ indoor air quality

${ }^{\text {a }}$ Concentration range retrieved from plot once precise figures are not given

${ }^{\mathrm{b}}$ Environmental tobacco smoke (ETS)

${ }^{\mathrm{c}}$ Median (means not reported)

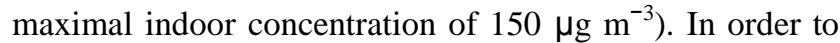
protect public health, regulatory aspects of air in relation to indoor $\mathrm{PM}_{2.5}$ need to be addressed. Some experts recommend indoor levels be maintained at $50 \%$ or less than air quality standards established by USEPA for outdoor air (Bernstein et al. 2008). However, PM does not have any threshold below which no health damage is observed. In order to minimize the health effects, WHO thus recommended guidelines (in ambient air) that represents an acceptable and achievable level of air pollution (WHO 2006). Concerning $\mathrm{PM}_{2.5}$, WHO advises that mean concentration should not exceed 25 and $10 \mu \mathrm{g} \mathrm{m}^{-3}$ within a period of $24 \mathrm{~h}$ and calendar year, respectively. As these guidelines are set for ambient air, they cannot be applied to indoor environments directly; on average, people spend 75$90 \%$ of their time indoors whereas it is only $10-25 \%$ outdoors. In the studied hospital, more than $50 \%$ of $\mathrm{PM}_{2.5}$ measured concentrations surpassed the 24-h guideline for ambient air which indicates the potential health risks of the exposed individuals. In addition, indoor particles can act as carrier for infectious microbes and microbial metabolites that may accumulate in the hospital environments (Hsu et al. 2012), thus representing additional health risks (i.e., transmissions of airborne infectious diseases; Eames et al. 2009; Tang et al. 2011; Hsu et al.2012).

\section{Elemental composition}

Twenty-one elements were determined by PIXE in indoor PM (Slezakova et al. 2012). Out of these, 11 elements were considered for health risk assessment: $\mathrm{Al}, \mathrm{Si}, \mathrm{Cl}, \mathrm{Mn}, \mathrm{Se}$, $\mathrm{Ba}, \mathrm{Cr}, \mathrm{Ni}, \mathrm{As}, \mathrm{Cd}$, and $\mathrm{Pb}$. Table 3 provides summary (means and ranges) of these 11 elements in $\mathrm{PM}_{2.5}$ and $\mathrm{PM}_{2.5-10}$. The total concentration of 11 elements (i.e., $\Sigma \mathrm{E}_{11}$ ) in air ranged between 271 and $1,030 \mathrm{ng} \mathrm{m}^{-3}$ for $\mathrm{PM}_{2.5}$ (mean of 759 $\mathrm{ng} \mathrm{m}^{-3}$ ) and between 134 and $793 \mathrm{ng} \mathrm{m}^{-3}$ for $\mathrm{PM}_{2.5-10}$ (mean of $349 \mathrm{ng} \mathrm{m}^{-3}$ ); $\Sigma \mathrm{E}_{11}$ comprised 26 and $25 \%$ of the elemental content in $\mathrm{PM}_{2.5}$ and $\mathrm{PM}_{2.5-10}$, respectively. Indoor elemental concentrations were compared with those from outdoor air from previous studies of the same team (Slezakova et al. 2012, 2007) in the selected area. Overall, outdoor mean $\Sigma \mathrm{E}_{11}$ ranged between 1,875 and $2,350 \mathrm{ng} \mathrm{m}^{-3}$ for $\mathrm{PM}_{2.5}$ and from 2,570 to 2,620 for $\mathrm{PM}_{2.5-10}$. The respective levels observed in the hospital were approximately two to three times lower for $\mathrm{PM}_{2.5}$ and seven to eight times for $\mathrm{PM}_{2.5-10}$.

Only few studies on PM elemental composition in hospital environments exist. From the available studies that are summarized in Table 2, only two of them (Brown et al. 2012; Wang et al. 2006a) presented results concerning PM composition. In Atlanta, USA, Brown et al. (2012) analyzed elemental compositions of $\mathrm{PM}_{2.5}$ in various microenvironments including one hospital. However, only limited results are presented for the hospital and with all data presented in plots. Thus the available information comes mainly from the study in Guangzhou, China (Wang et al. 2006a) where elemental concentrations ranged from 3,400 to $5,500 \mathrm{ng} \mathrm{m}^{-3}$ in $\mathrm{PM}_{2.5}$ and from 6,280 to $10,280 \mathrm{ng} \mathrm{m}^{-3}$ in $\mathrm{PM}_{10}$. These levels were approximately twice higher than in the present study (Table3), which is expected considering the higher pollution levels in Asian countries in general.

The compositional profiles of these elements were similar for both PM fractions. Out of the 11 considered elements, $\mathrm{Cl}$, 
$\mathrm{Si}$, and $\mathrm{Al}$ were the most dominant ones in both PM. These three elements accounted, respectively, for 85 and $90 \%$ of $\Sigma \mathrm{E}_{11}$ in $\mathrm{PM}_{2.5}$ and $\mathrm{PM}_{2.5-10}$. Specifically, $\mathrm{Cl}$ was the most abundant in $\mathrm{PM}_{2.5}\left(53 \%\right.$ of $\left.\Sigma \mathrm{E}_{11}\right)$ being followed by $\mathrm{Si}(19 \%$ of $\left.\Sigma \mathrm{E}_{11}\right)$ and $\mathrm{Al}(13 \%)$, whereas in coarse fraction $\mathrm{Si}$ accounted for the majority of $\Sigma \mathrm{E}_{11}(50 \%)$; $\mathrm{Cl}$ and $\mathrm{Al}$ contributed 30 and $13 \%$ of $\Sigma E_{11}$. The presence of $\mathrm{Cl}$ in indoor environments might result from cleaning works and use of cleaning products and disinfectants (Sulaiman et al. 2005), which are abundantly utilized in hospital environments. Dust released from building material can be also potential source of indoor $\mathrm{Cl}$ (Abdel Hameed et al. 2004). Considering that studied hospital is situated in a coastal area, indoor chloride may result from penetration of outdoor sea salt sprays particles (Slezakova et al. 2011b). Silicon and Al often result from crustal sources. The subsoil of this region consists of granite that is rich in $\mathrm{Al}$ and $\mathrm{Si}$ (Begonha 2001); granite is a common affordable material frequently also used indoors. Thus, presence of these elements in indoor environments might be due to the erosion of building materials or from penetration of outdoor particles to indoor ambiences (by air ventilation, lowquality building isolation, etc.).

The abundances of the other elements were for both PM much lower: $\mathrm{Ba}\left(2\right.$ and $5 \%$ of $\Sigma \mathrm{E}_{11}$ in $\mathrm{PM}_{2.5}$ and $\mathrm{PM}_{2.5-10}$, respectively), $\mathrm{Mn}\left(0.4\right.$ and $0.2 \%$ of $\Sigma \mathrm{E}_{11}$ in $\mathrm{PM}_{2.5}$ and $\mathrm{PM}_{2.5-}$ ${ }_{10}$, respectively), and $\mathrm{Se}\left(0.1 \%\right.$ in $\mathrm{PM}_{2.5}$ and $0.2 \%$ in $\mathrm{PM}_{2.5-}$ 10). Concerning carcinogenic elements, this study included three known carcinogens (USEPA group A) namely As, $\mathrm{Cr}$ and $\mathrm{Ni}$, and $\mathrm{Pb}$ that is considered as probable carcinogen based on animal studies (USEPA group B2). Total mean concentration of carcinogens $\left(\Sigma \mathrm{E}_{\text {carc }}\right)$ was 96.8 and $4.6 \mathrm{ng} \mathrm{m}^{-3}$ in $\mathrm{PM}_{2.5}$ and $\mathrm{PM}_{2.5-10}$, respectively, thus representing 13 and $1.3 \%$ of $\Sigma \mathrm{E}_{11}$. Specifically, the abundances of $\mathrm{Pb}, \mathrm{Ni}$, and $\mathrm{Cr}$ were low in both $\mathrm{PM}: \mathrm{Pb}(1$ and $0.2 \%$ of $\Sigma \mathrm{E}_{11}$ in $\mathrm{PM}_{2.5}$ and $\mathrm{PM}_{2.5-10}$, respectively), $\mathrm{Ni}$, and $\mathrm{Cr}\left(<1\right.$ and $<0.2 \%$, respectively, in $\mathrm{PM}_{2.5}$ and $\left.\mathrm{PM}_{2.5-10}\right)$; the concentrations of these three carcinogens were, at the Portuguese hospital, much lower than in the study of Wang et al. (2006a): 15-30 times for $\mathrm{Cr}, 7-13$ times for $\mathrm{Ni}$, and 20-30 times for $\mathrm{Pb}$. On the contrary, As comprised most of the carcinogenic content in both PM (83 and $60 \%$ of $\Sigma \mathrm{E}_{\text {carc }}$ in $\mathrm{PM}_{2.5}$ and $\mathrm{PM}_{2.5-10}$, respectively, i.e., 11 and $0.8 \%$ of $\left.\Sigma \mathrm{E}_{11}\right)$ and its levels $\left(\mathrm{PM}_{2.5}\right.$ mean of $\left.80.3 \mathrm{ng} \mathrm{m}^{-3}\right)$ were approximately twice higher than in the Chinese study (Wang et al. 2006a). No specific indoor source of As was identified in the hospital. In general, As is not typically an indoor pollutant but it can be found in indoor places with smoking (Slezakova et al. 2009); environmental tobacco smoke is its major indoor emission source. However, smoking was prohibited in all areas of the studied hospital. Considering also the predominant abundance of As in fine particles (97\%), contribution of anthropogenic outdoor emissions could account for indoor As. At this moment, there are no guidelines for concentrations of indoor PM-
Table 3 Mean concentrations of 11 studied elements in $\mathrm{PM}_{2.5}$ and $\mathrm{PM}_{2.5-10}$ at hospital $\left(\mathrm{ng} \mathrm{m}^{-3}\right)$

\begin{tabular}{llllll}
\hline & $\mathrm{PM}_{2.5}$ & & & \multicolumn{2}{l}{$\mathrm{PM}_{2.5-10}$} \\
\cline { 2 - 3 } \cline { 5 - 6 } & Mean & Range & & Mean & Range \\
\hline $\mathrm{Al}$ & 98.8 & $46.1-144$ & & 48.7 & $5.22-244$ \\
$\mathrm{Si}$ & 145 & $62.2-204$ & & 175 & $65.1-526$ \\
$\mathrm{Cl}$ & 406 & $177-591$ & & 104 & $28.0-279$ \\
$\mathrm{Mn}$ & 2.73 & $0.49-5.78$ & & 0.777 & $0.06-3.53$ \\
$\mathrm{Se}$ & 0.762 & $0.58-0.89$ & & 0.139 & $0.12-0.42$ \\
$\mathrm{Ba}$ & 9.00 & $4.26-18.4$ & & 16.1 & $2.61-55.4$ \\
$\mathrm{Cr}$ & 2.14 & $0.85-4.81$ & & 0.625 & $0.10-2.07$ \\
$\mathrm{Ni}$ & 3.02 & $0.77-7.74$ & & 0.506 & $0.07-1.96$ \\
$\mathrm{Cd}$ & $n . d$. & - & & .d. & - \\
$\mathrm{As}$ & 80.3 & $39.8-140$ & & 2.72 & $0.27-99.5$ \\
$\mathrm{~Pb}$ & 11.3 & $3.65-20.3$ & & 0.703 & $0.39-8.75$ \\
$\Sigma \mathrm{E}_{11}$ & 759 & $271-1,030$ & & 349 & $134-793$ \\
$\Sigma \mathrm{E}_{\text {total }}{ }^{\mathrm{a}}$ & 2,890 & $1,050-4,510$ & & 1,390 & $463-4,070$ \\
\hline
\end{tabular}

${ }^{a}$ Total elemental concentration (i.e., represents sum of 21 elements; Slezakova et al. 2012)

n.d. not detected

bound metals. Carcinogenic elements are considered in the European Directive 2004/107/EC (2005) which settles targets for $\mathrm{As}, \mathrm{Cd}$, and $\mathrm{Ni}$ in ambient air. The targets are expressed as annual means in $\mathrm{PM}_{10}$, with values of 6, 5, and $20 \mathrm{ng} \mathrm{m}^{-3}$ for $\mathrm{As}, \mathrm{Cd}$, and $\mathrm{Ni}$, respectively. Mean concentration of As in $\mathrm{PM}_{10}$ in hospital $\left(83.0 \mathrm{ng} \mathrm{m}^{-3}\right.$, i.e., sum of $\mathrm{PM}_{2.5}$ and $\mathrm{PM}_{2.5-}$ 10) was 14 times higher than the target value for ambient air. Finally, Cd (also considered as class A carcinogen) was absent in both PM in the studied hospital; this element was the least abundant in the study by Wang et al (2006a) with concentration ranging between 6 and $13 \mathrm{ng} \mathrm{m}^{-3}$.

PM health risks

The noncarcinogenic risks associated with inhalation exposure to particulate trace elements were calculated for three different age groups of hospital staff according to the USEPA methodology. The means and the ranges of THQ calculated for individual elements in different PM fractions and for various age groups of hospital staffs are presented in Table 4. The estimated mean THQ for $\mathrm{PM}_{2.5-10}$-bound trace elements ranged from $1.07 \times 10^{-6}$ for $\mathrm{Se}$ (adults, $55-64$ years) to $1.21 \times$ $10^{-9}$ for $\mathrm{Cl}$ (adults, 20-24 years). These results show that mean THQ of all nine elements in $\mathrm{PM}_{2.5-10}$, as well as total THQ (i.e., sum of individual THQ) were below the unity (THQ <1; Table 4) for all age categories of hospital staff. Therefore, noncarcinogenic risks from exposure to trace elements in coarse fraction were acceptable to all age groups of hospital staff. For $\mathrm{PM}_{2.5}$, significantly higher $\quad(p<0.05)$ 
Table 4 Risk assessment by target hazard quotients (THQ)

$\mathrm{Se}$

$\mathrm{Ba}$

$\mathrm{Cr}$

$\mathrm{Ni}$

As $\quad \Sigma_{\text {THQ }}$

Target hazard quotient for hospital staff (ET $8 \mathrm{~h}$ )

$\mathrm{PM}_{2.5}$

Adults 20-24 year

$3.45 \times 10^{-3} \quad 8.45 \times 10^{-3} \quad 4.73 \times 10^{-1}$

$\left(1.61-5.03 \times 10^{-3}\right) \quad\left(0.36-1.19 \times 10^{-2}\right) \quad\left(2.06-6.88 \times 10^{-1}\right)$

$\begin{array}{rrr}3.26 \times 10^{-3} & 7.98 \times 10^{-3} & 4.46 \times 10^{-1}\end{array}$

$9.52 \times 10^{-3}$

$8.99 \times 10^{-3}$

$\left..07-7.77 \times 10^{-6}\right)$

$6.28 \times 10^{-6}$

$\left(1.52-4.75 \times 10^{-3}\right) \quad\left(0.34-1.12 \times 10^{-2}\right) \quad\left(1.95-6.50 \times 10^{-1}\right)$

$\begin{array}{lll}3.05 \times 10^{-3} & 7.48 \times 10^{-3} & 4.18 \times 10^{-1}\end{array}$

\begin{tabular}{llllr}
$\left(1.42-4.45 \times 10^{-3}\right)$ & $\left(0.32-1.05 \times 10^{-2}\right)$ & $\left(1.82-6.09 \times 10^{-1}\right)$ & $\left(01.51-17.9 \times 10^{-3}\right)$ & $\left(4.48-688 \times 10^{-6}\right.$ \\
\hline
\end{tabular}

$\mathrm{PM}_{2.5-10}$

Adults 20-24 years

Adults 25-54 years

Adults 55-64 year

$1.70 \times 10^{-3} \quad 1.02 \times 10^{-2} \quad 1.21 \times 10^{-1}$

$\left(0.18-8.52 \times 10^{-3}\right) \quad\left(0.38-3.06 \times 10^{-2}\right) \quad\left(0.33-3.25 \times 10^{-1}\right)$

$\begin{array}{lll}1.60 \times 10^{-3} & 9.61 \times 10^{-3} & 1.14 \times 10^{-1}\end{array}$

$\left(0.17-8.05 \times 10^{-3}\right) \quad\left(3.58-28.9 \times 10^{-3}\right) \quad\left(0.31-3.07 \times 10^{-1}\right)$

$1.50 \times 10^{-3} \quad 9.01 \times 10^{-3} \quad 1.07 \times 10^{-1}$

$\left(0.16-7.54 \times 10^{-3}\right) \quad\left(3.35-27.1 \times 10^{-3}\right) \quad\left(0.29-2.87 \times 10^{-1}\right)$

Target hazard quotient for patients (ET $24 \mathrm{~h}$ )

$\mathrm{PM}_{2.5}$

Children $1-3$ years

Children 4-6 years

Children 7-10 years

Adolescents 11-14 years

Adolescents 15-

19 years

Adults 20-24 years

Adults $25-54$ years

Adults 55-64 year

Seniors $>65$ years

Children 1-3 years
$2.86 \times 10^{-2} \quad 7.01 \times 10^{-2} \quad 3.92$

$\left(1.34-4.17 \times 10^{-2}\right) \quad\left(3.00-9.85 \times 10^{-2}\right) \quad(1.71-5.71)$

$2.27 \times 10^{-2} \quad 5.55 \times 10^{-2} \quad 3.10$

$\left(1.06-3.30 \times 10^{-2}\right) \quad\left(2.38-7.80 \times 10^{-2}\right) \quad(1.35-4.52)$

$1.77 \times 10^{-2} \quad 4.34 \times 10^{-2} \quad 2.42$

$\left(0.83-2.58 \times 10^{-2}\right) \quad\left(1.86-6.09 \times 10^{-2}\right) \quad(1.06-3.53)$

$\begin{array}{lll}1.41 \times 10^{-2} & 3.45 \times 10^{-2} & 1.93\end{array}$

$\left(0.66-2.05 \times 10^{-2}\right) \quad\left(1.48-4.85 \times 10^{-2}\right) \quad(0.84-2.81$

$\begin{array}{lll}1.15 \times 10^{-2} & 2.81 \times 10^{-2} & 1.57\end{array}$

$\left(0.54-1.67 \times 10^{-2}\right) \quad\left(1.21-3.95 \times 10^{-2}\right) \quad(0.69-2.29)$

$1.04 \times 10^{-2} \quad 2.54 \times 10^{-2} \quad 1.42$

$\left(0.48-1.51 \times 10^{-2}\right) \quad\left(1.09-3.56 \times 10^{-2}\right) \quad(0.62-2.06)$

$9.77 \times 10^{-3} \quad 2.39 \times 10^{-2} \quad 1.34$

$\left(4.56-14.2 \times 10^{-3}\right) \quad\left(1.03-3.36 \times 10^{-2}\right) \quad(0.58-1.95)$

$9.16 \times 10^{-3} \quad 2.24 \times 10^{-2} \quad 1.25$

$\left(4.27-13.4 \times 10^{-3}\right) \quad\left(0.96-3.15 \times 10^{-2}\right) \quad(0.55-1.83)$

$8.80 \times 10^{-3} \quad 2.16 \times 10^{-2} \quad 1.21$

$\left(4.11-12.8 \times 10^{-3}\right) \quad\left(0.92-3.03 \times 10^{-2}\right) \quad(0.53-1.76)$ $\mathrm{PM}_{2.5-10}$

$1.41 \times 10^{-2} \quad 8.44 \times 10^{-2} \quad 10.1$

$\left(0.15-7.07 \times 10^{-2}\right) \quad\left(3.14-25.4 \times 10^{-2}\right) \quad(0.27-26.9)$
$2.40 \times 10^{-3}$

$1.07 \times 10^{-6}$

$4.88 \times 10^{-2}$

$3.41 \times 10^{-5}$

$2.53 \times 10^{-2}-1.77 \times 10^{-5}$

$2.43 \times 10^{-2}$

$1.70 \times 10^{-5}$

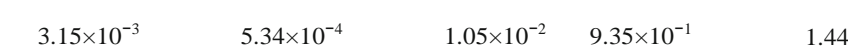

$\begin{array}{lrrrr}\left(1.49-6.43 \times 10^{-3}\right) & \left(2.13-12.0 \times 10^{-4}\right) & \left(0.27-2.70 \times 10^{-2}\right) & \left(4.63-16.3 \times 10^{-1}\right) & (0.68-2.39)\end{array}$

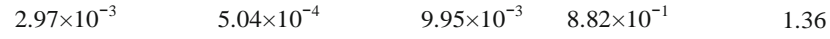

$\begin{array}{lllll}\left.1.40-6.07 \times 10^{-3}\right) & \left(2.01-11.3 \times 10^{-4}\right) & \left(2.54-25.5 \times 10^{-3}\right) & \left(4.3-15.4 \times 10^{-}\right) & (0.64-2.26)\end{array}$

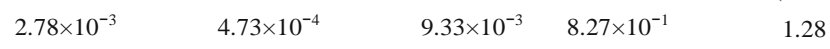

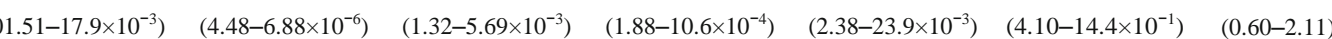

\section{$2.72 \times 10^{-3} \quad 1.21 \times 10^{-6}$}

$5.62 \times 10^{-3}$

$1.56 \times 10^{-4}$

$1.77 \times 10^{-3} \quad 3.17 \times 10^{-2}$

0.175

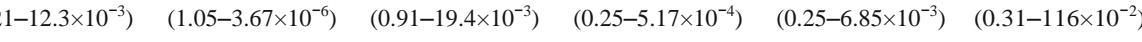

$2.56 \times 10^{-3} \quad 1.15 \times 10^{-6} \quad 5.30 \times 10^{-3}$

$1.47 \times 10^{-4}$

$1.67 \times 10^{-3} \quad 2.99 \times 10^{-2}$

$\left(4.11 \times 10^{-2}-1.56\right)$

$\begin{array}{llllll}\left(0.20-11.6 \times 10^{-3}\right) & \left(0.99-3.46 \times 10^{-6}\right) & \left(0.86-18.3 \times 10^{-3}\right) & \left(0.24-4.88 \times 10^{-4}\right) & \left(0.23-6.46 \times 10^{-3}\right) & \left(0.30-109 \times 10^{-2}\right)\end{array}$

$4.97 \times 10^{-3}$

$1.38 \times 10^{-4}$

$1.56 \times 10^{-3} \quad 2.80 \times 10^{-2}$

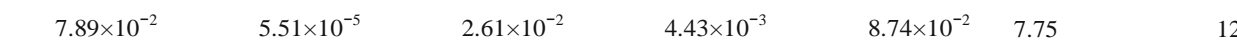

$\begin{array}{llllll}\left(01.42-16.7 \times 10^{-2}\right) & \left(4.20-6.44 \times 10^{-5}\right) & \left(1.23-5.33 \times 10^{-2}\right) & \left(1.77-9.95 \times 10^{-3}\right) & \left(2.23-22.4 \times 10^{-2}\right) & (3.48-13.5)\end{array}$

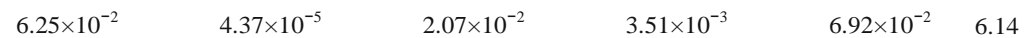

$\begin{array}{llllll}\left(1.12-11.3 \times 10^{-2}\right) & \left(3.3-5.11 \times 10^{-5}\right) & \left(0.98-4.22 \times 10^{-2}\right) & \left(1.40-7.88 \times 10^{-3}\right) & \left(1.77-17.8 \times 10^{-2}\right) & (3.04-10.7)\end{array}$

$1.61 \times 10^{-2}$

$2.74 \times 10^{-3}$

$5.41 \times 10^{-2} \quad 4.79$

$\begin{array}{llllll}\left(0.88-10.4 \times 10^{-2}\right) & \left(2.60-3.99 \times 10^{-5}\right) & \left(0.77-3.30 \times 10^{-2}\right) & \left(1.09-6.16 \times 10^{-3}\right) & \left(1.38-13.9 \times 10^{-2}\right) & (2.38-8.36)\end{array}$

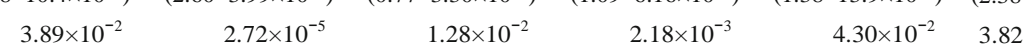

$\begin{array}{llllll}\left(0.70-8.24 \times 10^{-2}\right) & \left(2.07-3.17 \times 10^{-5}\right) & \left(0.61-2.62 \times 10^{-2}\right) & \left(0.89-4.90 \times 10^{-3}\right) & \left(1.10-11.0 \times 10^{-2}\right) & (1.89-6.66)\end{array}$

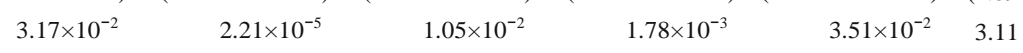

$\begin{array}{llllll}\left(0.57-6.72 \times 10^{-2}\right) & \left(1.69-2.59 \times 10^{-5}\right) & \left(4.95-2.14 \times 10^{-2}\right) & \left(0.71-4.00 \times 10^{-3}\right) & \left(0.90-9.00 \times 10^{-2}\right) & (1.54-5.43)\end{array}$

$2.86 \times 10^{-2} \quad 2.00 \times 10^{-5} \quad 9.44 \times 10^{-3}$

$1.60 \times 10^{-3} \quad 3.16 \times 10^{-2} \quad 2.80$

$\begin{array}{llllll}\left(0.51-6.06 \times 10^{-2}\right) & \left(1.52-2.33 \times 10^{-5}\right) & \left(4.47-19.3 \times 10^{-3}\right) & \left(0.64-3.60 \times 10^{-3}\right) & \left(0.81-8.11 \times 10^{-2}\right) & (1.39-4.89)\end{array}$

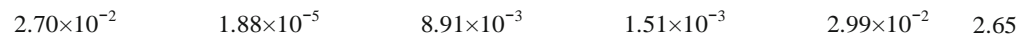

$\begin{array}{llllll}\left(0.49-5.72 \times 10^{-2}\right) & \left(1.43-2.20 \times 10^{-5}\right) & \left(4.21-18.2 \times 10^{-3}\right) & \left(0.60-3.40 \times 10^{-3}\right) & \left(0.76-7.66 \times 10^{-2}\right) & (1.31-4.62)\end{array}$

$2.80 \times 10^{-2} \quad 2.48$

$\begin{array}{llllll}\left(0.45-5.36 \times 10^{-2}\right) & \left(1.34-2.06 \times 10^{-5}\right) & \left(3.95-17.1 \times 10^{-3}\right) & \left(5.65-3.19 \times 10^{-3}\right) & \left(0.71-0.72 \times 10^{-2}\right) & (1.23-4.33)\end{array}$

$8.02 \times 10^{-3}$

$1.36 \times 10^{-3}$

$2.69 \times 10^{-2} \quad 2.38$

$\left(0.44-5.15 \times 10^{-2}\right) \quad\left(1.29-1.98 \times 10^{-5}\right) \quad\left(3.83-16.4 \times 10^{-3}\right) \quad\left(5.43-3.06 \times 10^{-3}\right) \quad\left(0.69-6.91 \times 10^{-2}\right) \quad(1.18-4.16)$

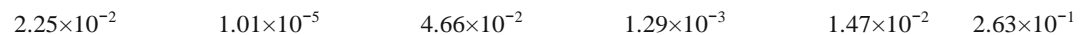

$\begin{array}{llllll}\left(0.17-10.2 \times 10^{-2}\right) & \left(0.87-3.04 \times 10^{-5}\right) & \left(0.76-16.0 \times 10^{-2}\right) & \left(0.21-4.28 \times 10^{-3}\right) & \left(0.20-5.68 \times 10^{-2}\right) & \left(0.26-96.1 \times 10^{-1}\right)\end{array}$
12.0

$(5.64-19.8)$

9.48

$(14.47-15.7)$

7.40

$(3.49-12.3)$

5.89

(2.78-9.76)

4.80

(2.27-7.96)

4.33

(2.04-7.17)

4.09

(1.93-6.77)

3.83

(1.81-6.34)

3.68

(1.74-6.10)

1.45

$\left(2.70 \times 10^{-1}-12.9\right)$ 


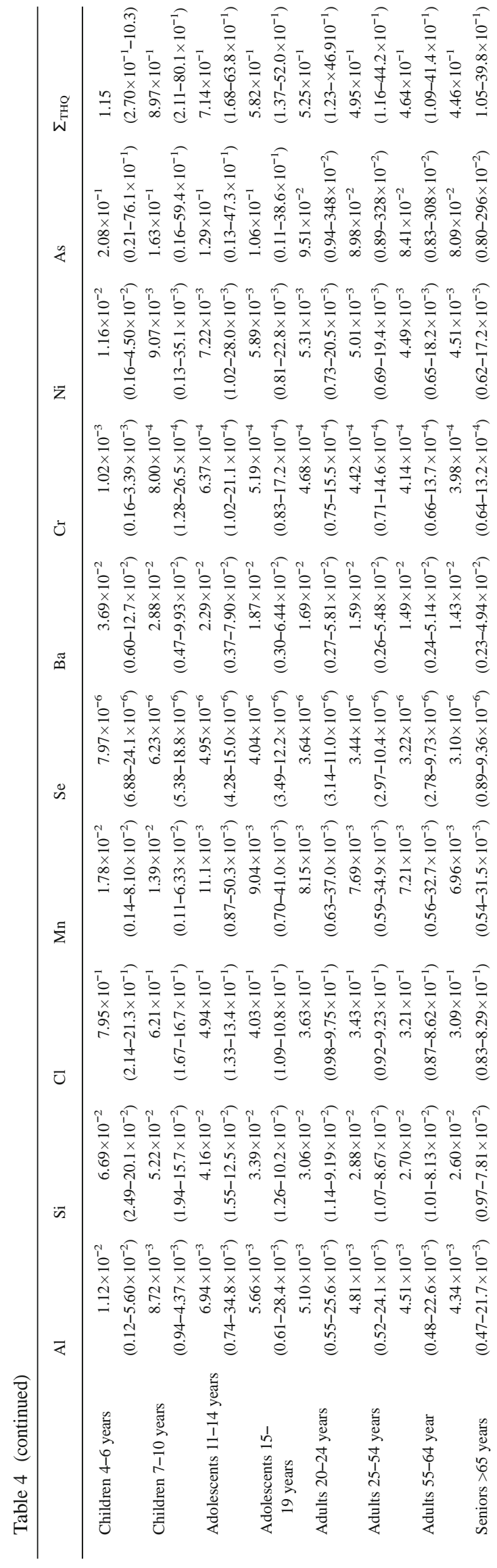

noncarcinogenic risks were observed with corresponding values ranging from $5.88 \times 10^{-6}$ for $\mathrm{Se}$ (adults, 55-64 years) to $9.35 \times 10^{-1}$ for As (adults, 20-24 years). As and $\mathrm{Cl}$ (the latter due to its high abundance) were the most important contributors (approximately $90 \%$ ) to noncarcinogenic risks. The contributions to THQ of other elements were significantly lower: $\mathrm{Ni}>\mathrm{Mn}>\mathrm{Si}>\mathrm{Al}>\mathrm{Ba}>\mathrm{Cr}>\mathrm{Se}$. For all these elements, individual THQ were below the unity (THQ <1) across all age groups. The total THQ in fine particles (Table 4) though exceeded safe level for all three age groups of hospital staff (with the greatest values, i.e., concerns, observed for younger populations), particularly due to the high contributions of As and $\mathrm{Cl}$.

The carcinogenic risks (means and ranges) of hospital staff associated with the exposure to PM-bound four carcinogenic elements are presented in Table 5. The obtained results demonstrate that (1) higher risks were found for metals in $\mathrm{PM}_{2.5}$ than $\mathrm{PM}_{2.5-10}$; (2) for all carcinogens, the highest carcinogenic risks were observed for the age group of adults with 5564 years); and (3) for all age groups, the highest risks were found for arsenic. Considering the aforementioned, the highest cancer risks were thus observed for arsenic in $\mathrm{PM}_{2.5}$ which reached for adults of 55-64 years a value of $6.19 \times 10^{-5}$. For carcinogenic risks, USEPA considers that setting a $10^{-6}$ risk level for individual chemicals and pathways will generally lead to negligible cancer risks. However, caution is recommended to ensure that the cumulative cancer risk for all potential carcinogenic contaminants does not have a residual cancer risk exceeding $\left(10^{-4}\right)$ (USEPA 2013a). As previously mentioned, the highest carcinogenic risks were observed for As (Table 5). In $\mathrm{PM}_{2.5}$, TR of As exceeded the USEPA guideline of $10^{-6}$ for all age categories of hospital staff (Table 5). Arsenic was the most threatening carcinogenic metal primarily due to its high PM content. The minimum As TR value (23 times higher than $10^{-6}$ ) corresponded to adults (2024 years) and maximum (62 times higher) to adults of 5564 years, mainly due to their lifetime exposure length. Concerning coarse particles, As cancer risks were significantly lower. Excess risks were observed for adults 55-64 years with As TR approximately twice higher (than $10^{-6}$ ). Cr was the second leading contributor to carcinogenic risks of hospital staff mostly due to its high value of inhalation unit risk. The inhalation unit risk of $\mathrm{Cr}(\mathrm{VI})$ is based on an assumed 1:6 ratio of $\mathrm{Cr}(\mathrm{III}): \mathrm{Cr}$ (VI) (USEPA 2013b). The concentration of $\mathrm{Cr}$ determined in this study was total $\mathrm{Cr}$. Therefore, one seventh of the total $\mathrm{Cr}$ (i.e., determined) concentration was used for health risk assessment. In $\mathrm{PM}_{2.5}$, the TR of $\mathrm{Cr}$ surpassed (two to five times) the USEPA guideline for all three age categories of hospital staff. Although $\mathrm{Cr}$ risks in coarse fraction were mostly negligible, one age category of adults of 55-64 years still exhibited TR values slightly higher than recommended. Regarding $\mathrm{Ni}$ and $\mathrm{Pb}$, the respective risks were inferior to those of As and Cr. Evaluating all age categories of hospital 
Table 5 Estimated target carcinogenic risks (TR) of PM-bound carcinogenic elements and $\mathrm{PM}_{2.5}$

\begin{tabular}{|c|c|c|c|c|c|c|}
\hline Age group & $\mathrm{Cr}$ & $\mathrm{Ni}$ & As & $\mathrm{Pb}$ & $\Sigma_{\mathrm{TR}}$ & $\mathrm{PM}_{2.5}$ \\
\hline & \multicolumn{6}{|c|}{$\mathrm{PM}_{2.5}$-bound carcinogenic elements } \\
\hline & \multicolumn{6}{|c|}{ Target carcinogenic risk for hospital staff (ET=8 h) } \\
\hline \multirow[t]{2}{*}{ Adults 20-24 years } & $1.68 \times 10^{-6}$ & $9.45 \times 10^{-8}$ & $2.25 \times 10^{-5}$ & $8.87 \times 10^{-9}$ & $2.43 \times 10^{-5}$ & $1.22 \times 10^{-2}$ \\
\hline & $\left(0.67-3.76 \times 10^{-6}\right)$ & $\left(2.41-24.2 \times 10^{-8}\right)$ & $\left(1.12-3.92 \times 10^{-5}\right)$ & $\left(2.86-15.9 \times 10^{-9}\right)$ & $\left(1.19-4.33 \times 10^{-5}\right)$ & $\left(0.58-2.19 \times 10^{-2}\right)$ \\
\hline \multirow[t]{2}{*}{ Adults $25-54$ years } & $2.09 \times 10^{-6}$ & $1.18 \times 10^{-7}$ & $2.81 \times 10^{-5}$ & $1.11 \times 10^{-8}$ & $3.04 \times 10^{-5}$ & $1.53 \times 10^{-2}$ \\
\hline & $\left(0.84-4.70 \times 10^{-6}\right)$ & $\left(0.30-3.03 \times 10^{-7}\right)$ & $\left(1.40-4.90 \times 10^{-5}\right)$ & $\left(0.36-1.99 \times 10^{-8}\right)$ & $\left(1.48-5.41 \times 10^{-5}\right)$ & $\left(0.72-2.74 \times 10^{-2}\right)$ \\
\hline \multirow[t]{3}{*}{ Adults 55-64 year } & $4.61 \times 10^{-6}$ & $2.60 \times 10^{-7}$ & $6.19 \times 10^{-5}$ & $2.44 \times 10^{-8}$ & $6.68 \times 10^{-5}$ & $3.36 \times 10^{-2}$ \\
\hline & $\left(1.84-10.3 \times 10^{-6}\right)$ & $\left(0.66-6.66 \times 10^{-7}\right)$ & $\left(3.07-10.8 \times 10^{-5}\right)$ & $\left(0.79-4.37 \times 10^{-8}\right)$ & $\left(3.26-11.9 \times 10^{-5}\right)$ & $\left(1.58-6.03 \times 10^{-2}\right)$ \\
\hline & \multicolumn{6}{|c|}{$\mathrm{PM}_{2.5-10}$-bound carcinogenic elements } \\
\hline \multirow[t]{2}{*}{ Adults $20-24$ years } & $4.89 \times 10^{-7}$ & $1.58 \times 10^{-8}$ & $7.64 \times 10^{-7}$ & $5.50 \times 10^{-10}$ & $1.27 \times 10^{-6}$ & \\
\hline & $\left(0.78-16.2 \times 10^{-7}\right)$ & $\left(0.22-6.14 \times 10^{-8}\right)$ & $\left(0.76-279 \times 10^{-7}\right)$ & $\left(3.05-68.5 \times 10^{-10}\right)$ & $\left(0.16-29.6 \times 10^{-6}\right)$ & \\
\hline \multirow[t]{2}{*}{ Adults $25-54$ years } & $6.11 \times 10^{-7}$ & $1.98 \times 10^{-8}$ & $9.55 \times 10^{-7}$ & $6.88 \times 10^{-10}$ & $1.59 \times 10^{-6}$ & \\
\hline & $\left(0.98-20.3 \times 10^{-7}\right)$ & $\left(0.27-7.67 \times 10^{-8}\right)$ & $\left(0.95-349 \times 10^{-7}\right)$ & $\left(3.82-85.6 \times 10^{-10}\right)$ & $\left(0.2-37.0 \times 10^{-6}\right)$ & \\
\hline \multirow[t]{2}{*}{ Adults 55-64 year } & $1.35 \times 10^{-6}$ & $4.36 \times 10^{-8}$ & $2.10 \times 10^{-6}$ & $1.51 \times 10^{-9}$ & $3.49 \times 10^{-6}$ & \\
\hline & $\left(0.22-4.46 \times 10^{-6}\right)$ & $\left(0.60-16.9 \times 10^{-8}\right)$ & $\left(0.21-76.8 \times 10^{-6}\right)$ & $\left(0.84-18.8 \times 10^{-9}\right)^{\backslash}$ & $\left(0.43-81.4 \times 10^{-6}\right)$ & \\
\hline \multirow[t]{2}{*}{ Age group } & \multicolumn{6}{|c|}{ Target carcinogenic risk for patients $(\mathrm{ET}=24 \mathrm{~h})$} \\
\hline & \multicolumn{6}{|c|}{$\mathrm{PM}_{2.5}$-bound carcinogenic elements } \\
\hline \multirow[t]{2}{*}{ Children $1-3$ years } & $2.51 \times 10^{-8}$ & $1.42 \times 10^{-8}$ & $3.38 \times 10^{-6}$ & $1.33 \times 10^{-9}$ & $3.64 \times 10^{-6}$ & $1.83 \times 10^{-3}$ \\
\hline & $\left(1.01-5.64 \times 10^{-7}\right)$ & $\left(0.36-3.63 \times 10^{-8}\right)$ & $\left(1.67-5.88 \times 10^{-6}\right)$ & $\left(0.43-2.39 \times 10^{-10}\right)$ & $\left(1.78-6.49 \times 10^{-6}\right)$ & $\left(0.86-3.29 \times 10^{-3}\right)$ \\
\hline \multirow[t]{2}{*}{ Children 4-6 years } & $1.01 \times 10^{-6}$ & $5.67 \times 10^{-8}$ & $1.35 \times 10^{-5}$ & $5.32 \times 10^{-9}$ & $1.46 \times 10^{-5}$ & $7.32 \times 10^{-3}$ \\
\hline & $\left(0.40-2.26 \times 10^{-6}\right)$ & $\left(1.45-14.5 \times 10^{-8}\right)$ & $\left(0.67-2.35 \times 10^{-5}\right)$ & $\left(1.71-9.54 \times 10^{-9}\right)$ & $\left(0.71-2.60 \times 10^{-5}\right)$ & $\left(3.44-13.2 \times 10^{-3}\right)$ \\
\hline \multirow[t]{2}{*}{ Children $7-10$ years } & $1.76 \times 10^{-6}$ & $9.92 \times 10^{-8}$ & $2.36 \times 10^{-5}$ & $9.31 \times 10^{-9}$ & $2.55 \times 10^{-5}$ & $1.28 \times 10^{-2}$ \\
\hline & $\left(0.71-3.95 \times 10^{-6}\right)$ & $\left(0.25-25.4 \times 10^{-8}\right)$ & $\left(1.17-4.12 \times 10^{-5}\right)$ & $\left(3.00-16.7 \times 10^{-9}\right)$ & $\left(1.25-4.54 \times 10^{-5}\right)$ & $\left(0.60-2.30 \times 10^{-2}\right)$ \\
\hline \multirow{2}{*}{$\begin{array}{l}\text { Adolescents } 11- \\
14 \text { years }\end{array}$} & $2.76 \times 10^{-6}$ & $1.57 \times 10^{-7}$ & $3.71 \times 10^{-5}$ & $1.46 \times 10^{-8}$ & $4.01 \times 10^{-5}$ & $2.01 \times 10^{-2}$ \\
\hline & $\left(1.10-6.21 \times 10^{-6}\right)$ & $\left(0.39-4.01 \times 10^{-7}\right)$ & $\left(1.84-6.47 \times 10^{-5}\right)$ & $\left(0.47-2.62 \times 10^{-8}\right)$ & $\left(1.96-7.14 \times 10^{-5}\right)$ & $\left(0.95-3.62 \times 10^{-2}\right)$ \\
\hline \multirow[t]{2}{*}{ Adolescents $15-19$ years } & $3.77 \times 10^{-6}$ & $2.13 \times 10^{-7}$ & $5.07 \times 10^{-5}$ & $1.99 \times 10^{-8}$ & $5.47 \times 10^{-5}$ & $2.75 \times 10^{-2}$ \\
\hline & $\left(0.15-8.47 \times 10^{-6}\right)$ & $\left(0.54-5.45 \times 10^{-7}\right)$ & $\left(2.51-8.83 \times 10^{-5}\right)$ & $\left(0.64-3.58 \times 10^{-9}\right)$ & $\left(2.67-9.73 \times 10^{-5}\right)$ & $\left(1.29-4.93 \times 10^{-2}\right)$ \\
\hline \multirow[t]{2}{*}{ Adults 20-24 years } & $5.03 \times 10^{-6}$ & $2.83 \times 10^{-7}$ & $6.75 \times 10^{-5}$ & $2.66 \times 10^{-8}$ & $7.29 \times 10^{-5}$ & $3.66 \times 10^{-2}$ \\
\hline & $\left(2.00-11.3 \times 10^{-6}\right)$ & $\left(0.72-7.27 \times 10^{-7}\right)$ & $\left(3.35-11.8 \times 10^{-5}\right)$ & $\left(0.86-4.77 \times 10^{-9}\right)$ & $\left(3.56-13.0 \times 10^{-5}\right)$ & $\left(1.72-6.58 \times 10^{-2}\right)$ \\
\hline \multirow[t]{2}{*}{ Adults $25-54$ years } & $6.28 \times 10^{-6}$ & $3.54 \times 10^{-7}$ & $8.44 \times 10^{-5}$ & $3.32 \times 10^{-8}$ & $9.11 \times 10^{-5}$ & $4.58 \times 10^{-2}$ \\
\hline & $\left(2.51-14.1 \times 10^{-6}\right)$ & $\left(0.90-9.08 \times 10^{-7}\right)$ & $\left(4.19-14.7 \times 10^{-5}\right)$ & $\left(1.07-5.97 \times 10^{-8}\right)$ & $\left(4.45-16.2 \times 10^{-5}\right)$ & $\left(2.15-8.22 \times 10^{-2}\right)$ \\
\hline \multirow[t]{2}{*}{ Adults 55-64 year } & $1.38 \times 10^{-5}$ & $7.79 \times 10^{-7}$ & $1.86 \times 10^{-4}$ & $7.31 \times 10^{-8}$ & $2.00 \times 10^{-4}$ & $1.01 \times 10^{-1}$ \\
\hline & $\left(0.55-3.10 \times 10^{-6}\right)$ & $\left(1.99-20.0 \times 10^{-7}\right)$ & $\left(0.92-3.24 \times 10^{-4}\right)$ & $\left(2.36-13.1 \times 10^{-8}\right)$ & $\left(0.98-3.57 \times 10^{-4}\right)$ & $\left(0.47-1.81 \times 10^{-1}\right)$ \\
\hline \multirow[t]{3}{*}{ Seniors $>65$ years } & $1.66 \times 10^{-5}$ & $9.35 \times 10^{-7}$ & $2.23 \times 10^{-4}$ & $8.78 \times 10^{-8}$ & $2.40 \times 10^{-4}$ & $1.21 \times 10^{-1}$ \\
\hline & $\left(0.66-3.73 \times 10^{-5}\right)$ & $\left(2.39-24.0 \times 10^{-7}\right)$ & $\left(0.11-3.88 \times 10^{-5}\right)$ & $\left(2.83-15.7 \times 10^{-8}\right)$ & $\left(1.17-4.28 \times 10^{-4}\right)$ & $\left(0.57-2.17 \times 10^{-1}\right)$ \\
\hline & $\mathrm{PM}_{2.5-10}$-bound car & rcinogenic elements & & & & \\
\hline Children $1-3$ years & $7.34 \times 10^{-8}$ & $2.38 \times 10^{-9}$ & $1.15 \times 10^{-7}$ & $8.25 \times 10^{-11}$ & $1.90 \times 10^{-7}$ & \\
\hline & $\left(1.17-24.3 \times 10^{-8}\right)$ & $\left(0.33-9.21 \times 10^{-9}\right)$ & $\left(0.11-41.9 \times 10^{-7}\right)$ & $\left(4.58-10.3 \times 10^{-11}\right)$ & $\left(0.24-44.5 \times 10^{-7}\right)$ & \\
\hline Children 4-6 years & $2.93 \times 10^{-7}$ & $9.51 \times 10^{-9}$ & $4.58 \times 10^{-7}$ & $3.30 \times 10^{-10}$ & $7.62 \times 10^{-7}$ & \\
\hline & $\left(0.47-9.72 \times 10^{-7}\right)$ & $\left(1.32-36.8 \times 10^{-9}\right)$ & $\left(0.45-167 \times 10^{-7}\right)$ & $\left(1.83-41.1 \times 10^{-10}\right)$ & $\left(0.94-17.8 \times 10^{-7}\right)$ & \\
\hline Children $7-10$ years & $5.14 \times 10^{-7}$ & $1.66 \times 10^{-8}$ & $8.02 \times 10^{-7}$ & $5.78 \times 10^{-10}$ & $1.33 \times 10^{-6}$ & \\
\hline & $\left(0.82-17.0 \times 10^{-7}\right)$ & $\left(0.23-6.44 \times 10^{-8}\right)$ & $\left(0.80-293 \times 10^{-7}\right)$ & $\left(3.21-71.9 \times 10^{-10}\right)$ & $\left(0.16-31.1 \times 10^{-6}\right)$ & \\
\hline Adolescents $11-14$ years & $8.07 \times 10^{-7}$ & $2.62 \times 10^{-8}$ & $1.26 \times 10^{-6}$ & $9.08 \times 10^{-10}$ & $2.09 \times 10^{-6}$ & \\
\hline & $\left(1.29-26.7 \times 10^{-7}\right)$ & $\left(0.36-10.1 \times 10^{-8}\right)$ & $\left(0.13-46.1 \times 10^{-6}\right)$ & $\left(5.04-113 \times 10^{-10}\right)$ & $\left(0.26-48.8 \times 10^{-6}\right)$ & \\
\hline Adolescents $15-19$ years & $1.10 \times 10^{-6}$ & $3.57 \times 10^{-8}$ & $1.72 \times 10^{-6}$ & $1.24 \times 10^{-9}$ & $2.86 \times 10^{-6}$ & \\
\hline & $\left(0.18-3.65 \times 10^{-6}\right)$ & $\left(0.49-13.8 \times 10^{-8}\right)$ & $\left(0.17-62.8 \times 10^{-6}\right)$ & $\left(0.69-15.4 \times 10^{-9}\right)$ & $\left(0.35-66.7 \times 10^{-6}\right)$ & \\
\hline Adults $20-24$ years & $1.47 \times 10^{-6}$ & $4.75 \times 10^{-8}$ & $2.29 \times 10^{-6}$ & $2.65 \times 10^{-9}$ & $3.81 \times 10^{-6}$ & \\
\hline & $\left(0.24-4.86 \times 10^{-6}\right)$ & $\left(0.66-18.4 \times 10^{-8}\right)$ & $\left(0.23-83.7 \times 10^{-6}\right)$ & $\left(0.92-20.5 \times 10^{-9}\right)$ & $\left(0.47-88.8 \times 10^{-6}\right)$ & \\
\hline Adults $25-54$ years & $1.83 \times 10^{-6}$ & $5.94 \times 10^{-8}$ & $2.86 \times 10^{-6}$ & $2.06 \times 10^{-9}$ & $4.76 \times 10^{-6}$ & \\
\hline
\end{tabular}


Table 5 (continued)

\begin{tabular}{|c|c|c|c|c|c|c|}
\hline Age group & $\mathrm{Cr}$ & $\mathrm{Ni}$ & As & $\mathrm{Pb}$ & $\Sigma_{\mathrm{TR}}$ & $\mathrm{PM}_{2.5}$ \\
\hline & $\left(0.29-6.08 \times 10^{-7}\right)$ & $\left(0.82-23.0 \times 10^{-8}\right)$ & $\left(0.28-105 \times 10^{-6}\right)$ & $\left(1.14-25.7 \times 10^{-9}\right)$ & $\left(0.59-111 \times 10^{-6}\right)$ & \\
\hline \multirow[t]{2}{*}{ Adults 55-64 year } & $4.04 \times 10^{-6}$ & $1.31 \times 10^{-7}$ & $6.30 \times 10^{-6}$ & $4.54 \times 10^{-9}$ & $1.05 \times 10^{-5}$ & \\
\hline & $\left(0.65-13.4 \times 10^{-6}\right)$ & $\left(0.18-5.06 \times 10^{-7}\right)$ & $\left(0.63-203 \times 10^{-6}\right)$ & $\left(2.52-56.5 \times 10^{-9}\right)^{\backslash}$ & $\left(0.13-24.4 \times 10^{-5}\right)$ & \\
\hline \multirow[t]{2}{*}{ Seniors $>65$ years } & $4.84 \times 10^{-6}$ & $1.57 \times 10^{-7}$ & $7.56 \times 10^{-6}$ & $5.45 \times 10^{-9}$ & $1.26 \times 10^{-5}$ & \\
\hline & $\left(0.78-16.0 \times 10^{-6}\right)$ & $\left(0.22-6.08 \times 10^{-7}\right)$ & $\left(00.75-276 \times 10^{-6}\right)$ & $\left(3.02-67.8 \times 10^{-9}\right)$ & $\left(0.16-29.3 \times 10^{-5}\right)$ & \\
\hline
\end{tabular}

staff, in $\mathrm{PM}_{2.5}$, the $\mathrm{TR}$ for $\mathrm{Ni}$ and $\mathrm{Pb}$ were 4-11 and 41-113 times lower than the threshold of $10^{-6}$, respectively, whereas it was 23-63 and 662-1,820 times for $\mathrm{Ni}$ and $\mathrm{Pb}$ in $\mathrm{PM}_{2.5-10}$. Therefore, carcinogenic risks resulting from occupational exposure to these two elements were negligible for all age categories. The total carcinogenic risks from occupational exposure to metals (i.e., sum of the individual TR) were also assessed for both PM fractions (Table 5). The results shows that total cancer risks of both PM fractions were higher than the USEPA-recommended level of $10^{-6}$ for all age groups of hospital staff. Specifically, TR values of $\mathrm{PM}_{2.5}$ were high (2467 times than acceptable). In addition, Table 5 also presents the carcinogenic risks calculated for inhalation exposure to indoor $\mathrm{PM}_{2.5}$ concentrations. For all three age groups, the carcinogenic risks from exposure to $\mathrm{PM}_{2.5}$ exceeded the USEPA cumulative threshold risk of $10^{-4}$ (risk of developing cancer over a human lifetime is 1 in 10,000), indicating adverse health outcomes across all age groups. The respective TR ranged from $1.22 \times 10^{-2}$ for adults (20-24 years), being the highest for adults of 55-64 years $\left(3.36 \times 10^{-2}\right)$. These results imply that 336 employees (55-64 years old) in 10,000 may have lung cancer due to $\mathrm{PM}_{2.5}$ exposure alone. The estimated risks might be even higher due to the synergistic effects between particulate matter and trace elements (Oeder et al. 2012).

The health risks analysis of this work was based on USEPA recommendation for workers (USEPA 2013a), with exposure frequency of 250 days per year (corresponds to 5 days per 50 weeks) and exposure time of $8 \mathrm{~h}$ per day (i.e., $40 \mathrm{~h}$ per week). Medical professionals often experience increased workloads (Cole et al. 2009) and long working hours; in some specializations such as general surgery or anesthesiology it is up to $60 \mathrm{~h}$ per week (Dorsey et al. 2003). Thus, the respective inhalation risks might be higher than those estimated here. Specifically for personnel with radiology specializations, the authors reported an average of $58 \mathrm{~h}$ per week (corresponds to $11.6 \mathrm{~h}$ per day; Dorsey et al. 2003). When ET of $11.6 \mathrm{~h}$ is considered, the re-estimated total THQ are approximately 1.5 times higher (1.85-2.09 and 0.22-0.25 for $\mathrm{PM}_{2.5}$ and $\mathrm{PM}_{2.5-}$ 10, respectively; Fig. 2a). Similarly, higher values for carcinogenic risks were obtained with re-estimated total $\mathrm{PM}_{2.5} \mathrm{TR}$ between $3.52 \times 10^{-5}$ and $9.69 \times 10^{-5}$ for adults with $20-24$ and 55-64 years, respectively; the corresponding TR in $\mathrm{PM}_{2.5-10}$ range from $1.84 \times 10^{-6}$ to $5.06 \times 10^{-6}$ (Fig. $2 b$ ). In essence, the major conclusions of the re-evaluated health risk analysis were the same, showing excess risks, both noncarcinogenic and carcinogenic ones, for $\mathrm{PM}_{2.5}$. It is also noteworthy that prolonged working hours caused excess cancer risks (TR two to five times higher than $10^{-6}$ ) of coarse fraction across all age categories of hospital staff. Typically, scientific attention is focused on fine particles. These results demonstrate that impacts of $\mathrm{PM}_{2.5-10}$ should not be omitted especially when prolonged exposures might occur. Although coarse particles are deposited in the upper parts of the respiratory system, they can cause additional risks. In that regard, it is necessary to consider that, on a daily basis, hospital staff is exposed to metals of both PM fractions. Cancer risks resulting from PMcombined exposure (i.e., sum of TR of both PM) exceeded the cumulative threshold of $10^{-4}$ for adults of 55-64 years. However, the respective risks could eventually be even higher if combined with alternative factors (lifestyle, smoking, diet, or additional outdoor exposure). When longer ET of $11.6 \mathrm{~h}$ was considered, As THQ ranged from 1.20 to 1.36 in $\mathrm{PM}_{2.5}$ and between $4.07 \times 10^{-2}$ and $4.60 \times 10^{-2}$ in $\mathrm{PM}_{2.5-10}$, carcinogenic risks were $3.26 \times 10^{-5}-8.98 \times 10^{-5}$ in $\mathrm{PM}_{2.5}$ and $1.10 \times 10^{-6}-$ $3.05 \times 10^{-6}$ in $\mathrm{PM}_{2.5-10}$. In $\mathrm{PM}_{2.5}$, As THQ and TR were of particular concern as they exceeded both unity and USEPA threshold, respectively, across all age categories.

Finally, the noncarcinogenic and carcinogenic risks were also estimated for nine different age categories of patients (ET of $24 \mathrm{~h}$ ). The results are shown in Tables 4 and 5, respectively. Overall THQ and TR values of adult patients were approximately three times higher than for hospital staff, mostly due to the longer exposure. Particular concerns were observed for children ( $\Sigma$ THQ 7.40-12.0 in $\mathrm{PM}_{2.5} ; 1.15-1.45$ in $\mathrm{PM}_{2.5-10}$ ). These findings are relevant because young children have lower tolerance to toxins (Acosta et al. 2009). In addition, due to their behavior (hand-to-mouth activities, touching and mouthing of various dust-contaminated objects; Beamer et al. 2008) children exposure to metals might be even higher (indirectly by indigestion) which could result in increased risks than here estimated. Total carcinogenic risks from inhalation exposure to metals (i.e., $\Sigma \mathrm{TR}$ ) exceeded in $\mathrm{PM}_{2.5}$ USEPA guideline of $10^{-6}$ across all age categories of patients with TR values ranging from 4 (children, 1-3 years) to 240 (seniors) times higher than acceptable (Table 5). These results 
Fig. 2 Risks from inhalation exposure to particulate-bound metals for three age groups of hospital personnel (exposure time (ET) of 8 and $11.6 \mathrm{~h}$ per day); a noncarcinogenic and $b$ carcinogenic. THQ and TR values are estimated as sum of individual noncarcinogenic and carcinogenic risk values of ten and four elements, respectively, in $\mathrm{PM}_{2.5}$, $\mathrm{PM}_{2.5-10}$ and in total PM (i.e., $\mathrm{PM}_{2.5}+\mathrm{PM}_{2.5-10}$ ). Horizontal black lines indicate USEPA health-based guideline levels (THQ $=1$ and TR of $10^{-6}$ and $10^{-4}$ )
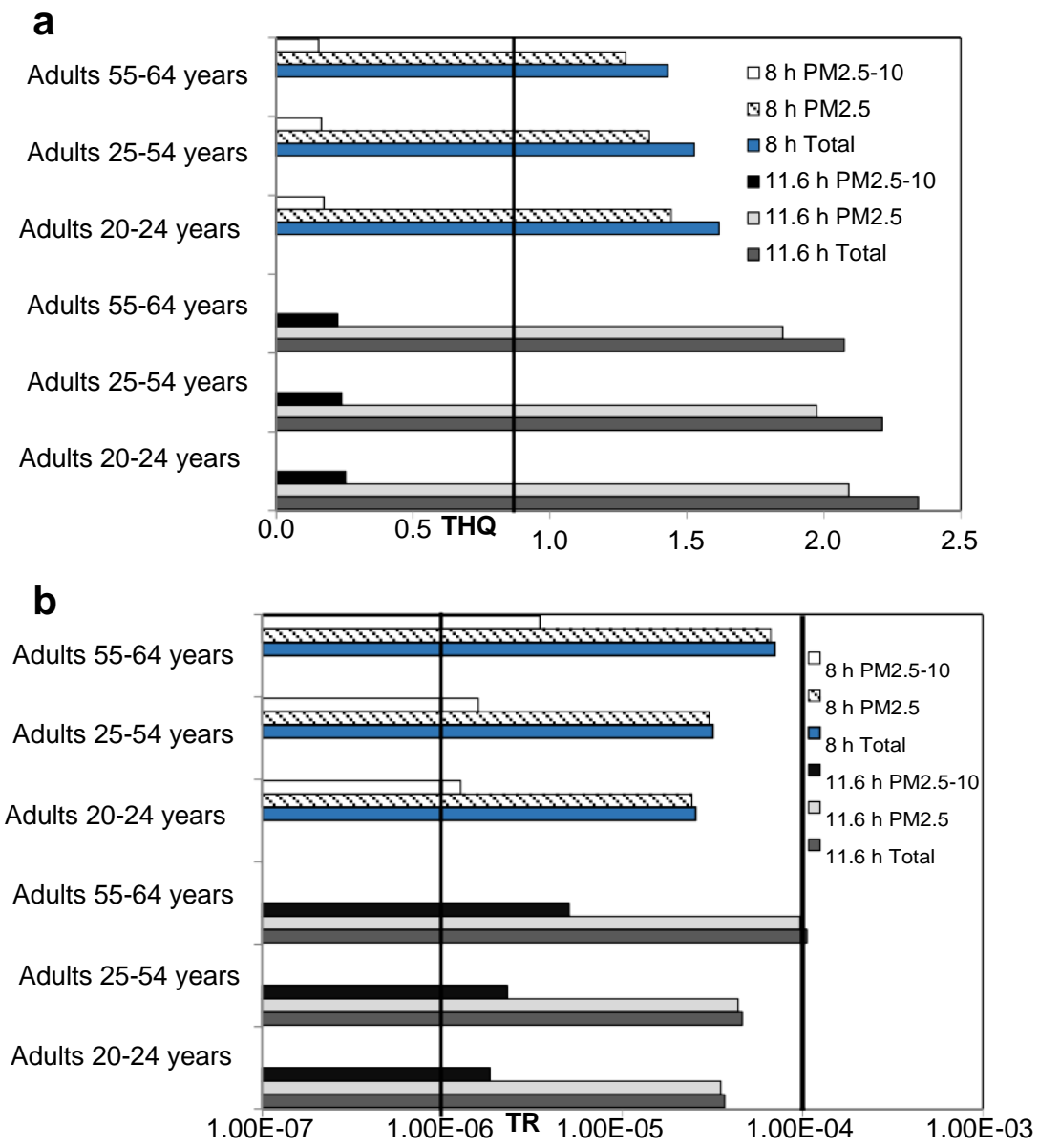

indicate that inhalation exposure to metals in fine particles at the levels observed in hospitals might eventually lead to adverse health outcomes (i.e., lung cancer morbidity and mortality) for all age groups (Valavanidis et al. 2008). Finally, as demonstrated in Fig. 3a, b, the additive noncarcinogenic and carcinogenic risks of metals in both PM fractions (i.e., $\mathrm{PM}_{2.5}+\mathrm{PM}_{2.5-10}$ ) exceeded, for all age categories of patients, the USEPA safe levels (THQ $>1$; TR $>10^{-6}$ ). Additive carcinogenic risks from long-term exposures (adults, 55-64 years and seniors) were of particular concern as they resulted in TR values that exceeded USEPA cumulative threshold of $10^{-4}$. In some cases, due to suppressed immune system, patients may be more susceptible to external influences, so the respective risks for the patients can be higher than estimated here. Studies have shown that hospital patients can acquire microbial contaminants (bacteria, fungi, and viruses) from personnel and from indoor environment (Napoli et al. 2012). Although the extent to which the latter contributes towards hospitalacquired infection is largely unknown (Talon 1999), the environmental matrices such as air and surfaces can act as reservoirs of microbial contaminants. The risks due to the biological component have not been considered in this study. However, suspended particles are particularly important in that regard because they can carry and transport microorganisms, secondary allergens, or proinflammatory compounds (Balaras et al. 2007). There is increasing evidence that PM biological components play central role in biological effects. When PM is inhaled, biological components are responsible for stimulating alveolar macrophages and respiratory epithelial tissue to release proinflammatory cytokines and chemokines (Nemmar et al 2013). Even when hospital environment is well within the recommended limits of microbiological air quality, the number of particles may be high (and consequently foster the growth of microorganisms; Dascalaki et al. 2008). In order to reduce bacteria, viruses, and particle concentrations in hospital, proper air ventilation and its maintenance are mandatory so safe and healthy air environment can be obtained. Particular attention needs to be given to cleaning and prevention of microbial growth indoors (Dancer 2004).

In addition when assessing human risks, metal speciation is of major importance. This might be especially relevant for As and $\mathrm{Cr}$ that were the major contributors to TR risks of the exposed populations in hospitals. Arsenic has a complex chemical structure and can be found in inorganic (trivalent and pentavalent) or organic forms. Whereas the inorganic As is considered by USEPA as class 1 carcinogen, its alkylated 
Fig. 3 Risks from inhalation exposure to particulate bound metals for nine age categories of patients (ET of $24 \mathrm{~h}$ per day); a noncarcinogenic and $b$ carcinogenic. The TR and THQ

values represent, respectively, sum of individual risks of ten and four elements in $\mathrm{PM}_{2.5}, \mathrm{PM}_{2.5-10}$, and in total PM (i.e., $\mathrm{PM}_{2.5}+$ $\mathrm{PM}_{2.5-10}$ ). Horizontal black lines represent USEPA health-based guideline levels $(\mathrm{THQ}=1$ and $\mathrm{TR}$ of $10^{-6}$ and $10^{-4}$ ) a

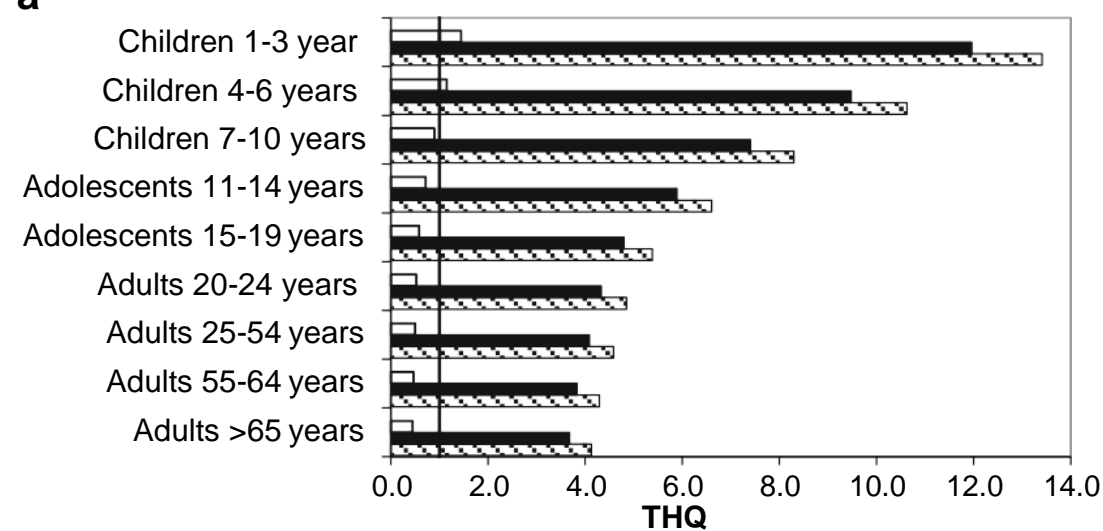

b

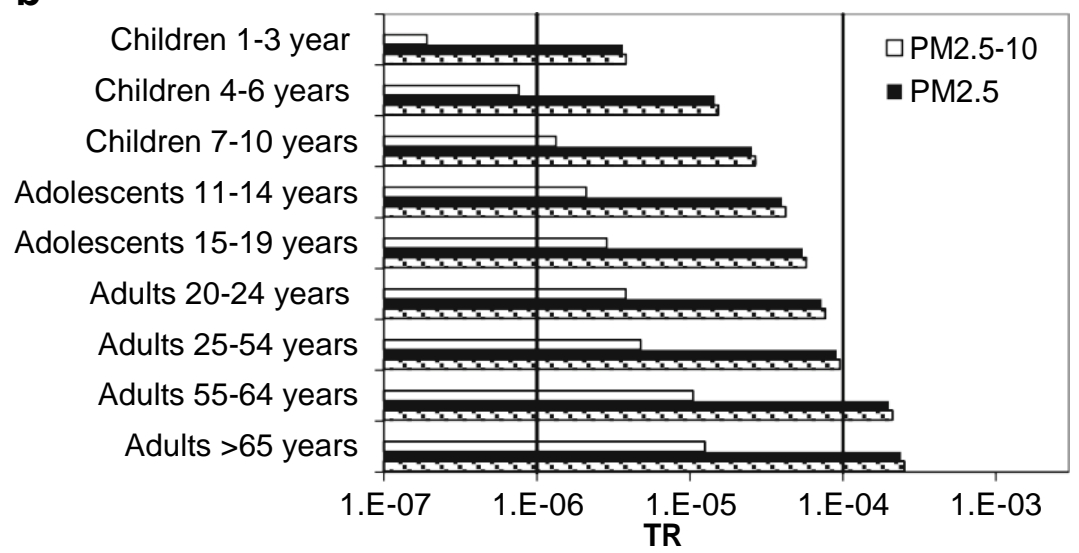

forms can be less toxic (Morais et al. 2012). In this study, the content of the particulate-bound elements were determined considering the total concentration (only). Concerning $\mathrm{Cr}$, its toxicity also depends on the chemical form and subsequent bioavailability (Michalski 2009). Cr(III) are compounds essential to human whereas $\mathrm{Cr}(\mathrm{VI})$ is toxic and carcinogenic. In this case study, risk assessment was performed using one seventh of the determined total $\mathrm{Cr}$ concentration based on the assumption 1:6 ratio of $\mathrm{Cr}$ (III): Cr(VI) (USEPA 2013b). Nevertheless, deeper insight to the chemical speciation of PMbound metals is particularly important for future health risks assessment studies of indoor air pollution. Finally, it should be mentioned that there are no similar studies in the literature with which the present results of exposure risks might be compared.

\section{Conclusions}

In this work, the risks associated with inhalation exposure to particulate-bound trace metals in hospital environment were estimated. Hospital staff and patients were considered as the exposed groups.
Noncarcinogenic risks associated with inhalation exposure to $\mathrm{PM}_{2.5-10}$-bound metals were acceptable to all age groups of hospital personnel whereas for fine fraction, total noncarcinogenic risks were above the safe level for all three age categories of hospital staff. Total carcinogenic risks in $\mathrm{PM}_{2.5}$ highly (up to 67 times) exceeded the recommended level for the three age groups of hospital personnel, thus clearly showing that occupational exposure to metals in fine particles poses significant risks. If the extensive working hours of hospital medical staff were considered, the noncarcinogenic and carcinogenic risks were increased, the latter exceeding the USEPA cumulative guideline of $10^{-4}$.

The noncarcinogenic and carcinogenic risks of adult patients were approximately three times higher than for personnel. Particular concerns (THQ $>1, \mathrm{TR}>10^{-6}$ ) were observed for children and adolescents.

Hospitals are important public places where indoor air quality has a significant role on the potential health outcomes (both patients and employees). Even if the levels of respective indoor pollutants are low, the potential risks cannot be ignored considering long-term exposures in these environments. Therefore, when assessing the health risks in hospital, the specificity of exposure times should be considered. The noncarcinogenic and carcinogenic risks estimated in this work 
were via inhalation route. However, exposure to metals occurs also via ingestion and dermal contact and if these routes are considered, the estimated risks might be higher. Moreover and if possible, metals speciation should be characterized in several PM fractions.

Acknowledgments This work was supported by Fundação para Ciência e Tecnologia through grants PEst-C/EQB/LA0006/2011 and PEst-C/EQB/UI0511/2011 and fellowship SFRH/BPD/65722/2009. The authors would like to acknowledge Professor Maria do Conceição Alvim-Ferraz from Faculdade de Engenharia da Universidade do Porto and all collaborators from Centro Hospitalar de Vila Nova de Gaia.

\section{References}

Abdel Hameed AA, Yasser IH, Khoder IM (2004) Indoor air quality during renovation action: a case study. J Environ Monitor 6:740744

Acosta JA, Cano AF, Arocena JM, Debela F, Martinez-Martinez S (2009) Distribution of metals in soil particle size fractions and its implication to risk assessment of playground in Murcia City (Spain). Geoderma 149:101-109

Almeida SM, Reis MA, Freitas MC, Pio CA (2003) Quality assurance in elemental analysis of airborne particles. Nucl Instrum Methods Phys Res Sect B-Beam Interact Mater Atoms 207:434-446

Atkinson RW, Fuller GW, Anderson HR, Harrison RM, Armstrong B (2010) Urban ambient particle metrics and health. A time-series analysis. Epidemiology 21:501-511

Balaras CA, Dascalaki E, Gaglia A (2007) HVAC and indoor thermal conditions in hospital operating rooms. Energy Build 39:454-470

Banse JP (2013) IAQ, infection control in hospitals. Consult Specif Eng 50(1):28-32

Barnett R, Barnett P (2003) "If you want to sit on your butts you'll get nothing!" Community activism in response to threats of rural hospital closure in southern New Zealand. Health Place 9:59-71

Beamer P, Key ME, Ferguson AC, Canales RA, Auyeung W, Leckie JO (2008) Quantified activity pattern data from 6 to 27 month-old farmworker children for use in exposure assessment. Environ Res 108:239-246

Begonha A (2001) Meteorização do granito e deterioração da pedra em monumentos e edifícios da cidade do Porto. FEUP-EdiçõesColecção Monografias, Porto

Bernstein JA, Alexis N, Bacchus H, Bernstein IL, Fritz P, Horner ELN, Mason S, Nel A, Oullette J, Reijula K, Reponen T, Seltzer J, Smith A, Tarlo SM (2008) The health effects of nonindustrial indoor air pollution. J Allergy Clin Immunol 12:585-591

Brown KB, Sarnat JA, Koutrakis P(2012) Concentrations of PM2.5 mass and components in residential and non-residential indoor microenvironments: The sources and composition of particulate exposures study. J Expo Sci Environ Epidemiol 22:161-172

Brunekreef B, Beelen R, Hoek G, Schouten L, Bausch-Goldbohm S, Fischer P, Armstrong B, Hughes E, Jerrett M, van den Brandt P (2009) Effects of long-term exposure to traffic-related air pollution on respiratory and cardiovascular mortality in the Netherlands: The NLCS-AIR study. Res Rep Health Eff Inst 139:5-71, discussion 73-89

Castro D, Slezakova K, Delerue-Matos C, Alvim-Ferraz MC, Morais S, Pereira MC (2011) Polycyclic aromatic hydrocarbons in gas and particulate phases of indoor environments influenced by tobacco smoke: Levels, phase distributions, and health risks. Atmos Environ 45(10):1799-1808
Chattopadhyay G, Lin KC, Feitz AJ (2003) Household dust metal levels in the Sydneymetropolitan area. Environ Res 93:301-307

Chen LC, Lippmann M (2009) Effects of metals within ambient air particulate matter (PM) on human health. Inhal Toxicol 21:131

Cole DC, Koehoorn M, Ibrahim S, Hertzman C, Ostry A, Xu F, Brown P (2009) Regions, hospitals and health outcomes over time: A multilevel analysis of repeat prevalence among a cohort of health-care workers. Health Place 15:1046-1057

Dancer SJ (2004) How do we assess hospital cleaning? A proposal for microbiological standards for surface hygiene in hospitals. J Hosp Infect 56(1):10-15

Dascalaki EG, Lagoudi A, Balaras CA, Gaglia AG (2008) Air quality in hospital operating rooms. Build Environ 43(11):1945-1952

DecretoLei 79/2006(2006)O Regulamento dos Sistemas Energéticos de Climatização em Edifícios (RSECE). Diário da Republica, 1 sériaA $67: 2414-2167$

Directive 2004/107/EC (2005) Directive of the European Parliament and of the Council relating to arsenic, cadmium, mercury, nickel and polycyclic aromatic hydrocarbons in ambient air. Official Journal of the European Union L23:3-16

Dong C, Yang L, Yan C, Yuan Q, Yu Y, Wang W (2013) Particle size distributions, PM2.5 concentrations and water-soluble inorganic ions in different public indoor environments: a case study in Jinan, China. Front Environ Sci Eng 7(1):55-65

Dorsey ER, Jarjoura D, Rutecki GW (2003) Influence of controllable lifestyle on recent trends in specialty choice by US medical students. JAMA 290:1173-1178

Eames I, Tang JW, Li Y, Wilson P (2009) Airborne transmission of disease in hospitals. J R Soc Interface 6:S697-S702

Fang GC, Huang YL, Huang JH (2010) Study of atmospheric metallic elements pollution in Asia during 2000-2007. J Hazard Mater 180: $115-121$

Fernández E, Martínez C, Fu M, Martínez-Sánchez JM, López MJ, Invernizzi G, Ouranou A, Dautzenberg B, Nebot M (2009) Second-hand smoke exposure in a sample of European hospitals. Eur Respir J 34:111-116

Freitas MC, Almeida SM, Reis MA, Oliveira OR(2003) Monitoring trace elements by nuclear techniques in PM10 and PM2.5. Nucl Instrum Methods Phys Res Sect A-Accel Spectrom Dect Assoc Equip 505: 430-434

Gent JF, Koutrakis P, Belanger K, Triche E, Holford TR, Bracken MB, Leaderer BP (2009) Symptoms and medication use in children with asthma and traffic related sources of fine particle pollution. Environ Health Perspect 117:1168-1174

Greene NA, Morris VR (2006) Assessment of public health risks associated with atmospheric exposure to PM2.5 in Washington, DC, USA. Int J Environ Res Public Health 3:86-97

Habil M, Massey DD, Taneja A (2013) Exposure of children studying in schools of India to PM levels and metal contamination: sources and their identification. Air Qual Atmos Health 6:575-587

Hassan SKM (2012) Metal concentrations and distribution in the household, stairs and entryway dust of some Egyptian homes. Atmos Environ 54:207-215

Hoek G, Krishnan RM, Beelen R, Peters A, Ostro B, Brunekreef B, Kaufman JD (2013) Long-term air pollution exposure and cardiorespiratory mortality: a review. Environ Health 12(1):43

Hsu Y-C, Kung P-Y, Wu T-N, Shen Y-H (2012) Characterization of indoor-air bioaerosols in Southern Taiwan. AAQR 12:651-661

Hu X, Zhang Y, Ding Z, Wang T, Lian H, Sun Y, Wu J (2012) Bioaccessibility and health risk of arsenic and heavy metals $(\mathrm{Cd}$, $\mathrm{Co}, \mathrm{Cr}, \mathrm{Cu}, \mathrm{Ni}, \mathrm{Pb}, \mathrm{Zn}$ and $\mathrm{Mn}$ ) in TSP and PM2.5 in Nanjing, China. Atmos Environ 57:146-152

Huboyo HS, Tohno S, Cao R (2011) Indoor PM2.5 characteristics and $\mathrm{CO}$ concentration related to water-based and oil-based cooking emissions using a gas stove. AAQR 11:401-411 
Hulin M, Simoni M, Viegi G, Annesi-Maesano I (2012) Respiratory health and indoor air pollutants based on quantitative exposure assessments. Eur Respir J 40(4):1033-1045

IARC Working Group on the Evaluation of Carcinogenic Risks to Humans (2006) Inorganic and organic lead compounds. IARC Monogr Eval Carcinog Risks Hum 87:1-471

IARC Working Group on the Evaluation of Carcinogenic Risks to Humans (2012) Arsenic, metals, fibres, and dusts. IARC Monogr Eval Carcinog Risks Hum 100(PtC):11-465

Kebede K, Kefeni KK, Okonkwo JO (2013) Trace metals, anions and polybromodiphenyl ethers in settled indoor dust and their association. Environ Sci Pollut Res 20:4895-4905

Kelly FJ, Fussell JC (2012) Size, source and chemical composition as determinants of toxicity attributable to ambient particulate matter. Atmos Environ 60:504-526

Klepeis NE, Nelson WC, Ot WR, Robinson JP, Tsang AM, Switzer P, Behar JV, Hern SC, Engelmann WH (2001) The National Human Activity PatternSurvey(NHAPS): aresource for assessing exposure to environmental pollutants. J Expo Anal Environ Epidemiol 11: 231-252

Kurt-Karakus PB (2012) Determination of heavy metals in indoor dust from Istanbul, Turkey: estimation of the health risk. Environ Int 50: $47-55$

Li P, Xin J, Wang Y, Wang S, Li G, Pan X, Liu Z, Wang L (2013) The acute effects of fine particles on respiratory mortality and morbidity in Beijing, 2004-2009. Environ Sci Pollut Res 20(9):6433-6444

Lü S, Zhang R, Yao Z, Yi F, Ren J, Wu M, Feng M, Wang Q (2012) Size distribution of chemical elements and their source apportionment in ambient coarse, fine, and ultrafine particles in Shanghai urban summer atmosphere. J Environ Sci (China) 24:882-890

Maynard D, Coull BA, Gryparis A, Schwartz J (2007) Mortality risk associated with short-term exposure to traffic particles and sulfates. Environ Health Perspect 11:751-755

Michalski R (2009) Applications of ion chromatography for the determination of inorganic cations. Crit Rev Anal Chem 39(4):230-250

Minguillón MC, Schembari A, Triguero-Mas M, de Nazelle A, Dadvand P, Figueras F, Salvado JA, Grimalt JO, Nieuwenhuijsen M, Querol X (2012) Source apportionment of indoor, outdoor and personal PM 2.5 exposure of pregnant women in Barcelona, Spain. Atmos Environ 59:426-436

Mitchell CS, Zhang JJ, Sigsgaard T, Jantunen M, Lioy PJ, Samson R, Karol MH (2007) Current state of the science: health effects and indoor environmental quality. Environ Health Perspect 115:958-964 Morais S, Garcia e Costa F, Pereira ML (2012) Thoughts on evaluation of heavy metals. In: Taylor JC (ed) Advances in chemical research volume 14. Nova Science Publishers, Inc., Hauppauge, pp 273-279 Napoli C, Marcotrigiano V, Montagna MT (2012) Air sampling proce- dures to evaluate microbial contamination: a comparison between active and Health 12:594

passive methods in operating theatres. BMC Public

Nardini S, Cagnin R, Invernizzi G, Ruprecht A, Boffi R, Formentini S (2004) Indoor particulate matter measurement as a tool in the process of the implementation of smoke-free hospitals. Monaldi Arch Chest Dis 61:183-192

Nemmar A, Holme JA, Rosas I, Schwarze PE, Alfaro-Moreno E (2013) Recent advances in particulate matter and nanoparticle toxicology: a review of the in vivo and in vitro studies. Biomed Res Int 2013:279371

Oeder S, Dietrich S, Weichenmeier I, Schober W, Pusch G, Jörres RA, Schierl R, Nowak D, Fromme H, Behrendt H, Buters JT (2012)

Toxicity and elemental composition of particulate matter from out- door and indoor air of elementary schools in Munich, Germany. Indoor Air 22:148-158

Okuda T, Katsuno M, Naoi D, Nakao S, Tanaka S, He K, Ma Y, Lei Y, Jia $\mathrm{Y}(2008)$ Trends in hazardous trace metal concentrations in aerosols collected in Beijing, China from 2001 to 2006. Chemosphere 7:917924
Paoletti L, De Berardis B, Arrizza L, Granato V (2006) Influence of tobacco smoke on indoor PM10 particulate matter characteristics. Atmos Environ 40:3269-3280

Polichetti G, Cocco S, Spinali A, Trimarco V, Nunziata A (2009) Effects of particulate matter $(\mathrm{PM}(10), \mathrm{PM}(2.5)$ and $\mathrm{PM}(1))$ on the cardiovascular system. Toxicology 264:1-8

Sarnat JA, Marmur A, Klein M, Kim E, Russell AG, Sarnat SE, Mulholland JA, Hopke PK, Tolbert PE (2008) Fine particle sources and cardiorespiratory morbidity: an application of chemical mass balance and factor analytical source-apportionment methods. Environ Health Perspect 116:459-466

Schwarze PE, Ovrevik J, Låg M, Refsnes M, Nafstad P, Hetland RB, Dybing E (2006) Particulate matter properties and health effects: consistency of epidemiological and toxicological studies. Hum Exp Toxicol 25(10):559-579

Senlin L, Zhenkun Y, Xiaohui C, Minghong W, Guoying S, Jiamo F, Paul D (2008) The relationship between physicochemical characterization and the potential toxicity of fine particulates (PM2.5) in Shanghai atmosphere. Atmos Environ 42:7205-7214

Singh DP, Gadi R, Mandal TK (2011) Characterization of particulatebound polycyclic aromatic hydrocarbons and trace metals composition of urban air in Delhi, India. Atmos Environ 45:7653-7663

Slezakova K, Pereira MC, Reis MA, Alvim-Ferraz MC (2007) Influence of traffic emissions on the composition of atmospheric particles of different sizes - Part 1: concentrations and elemental characterization. J Atmos Chem 58:55-68

Slezakova K, Pires JCM, Pereira MC, Martins FG, Alvim-Ferraz MC (2008) Influence of traffic emissions on composition of atmospheric particles of different sizes - part 2: SEM-EDS characterization. $\mathbf{J}$ Atmos Chem60:221-236

Slezakova K, Pereira MC, Alvim-Ferraz MC (2009) Influence of tobacco smoke on the elemental composition of indoor particles of indoor sizes. Atmos Environ 43:486-493

Slezakova K, Castro D, Begonha A, Delerue-Matos C, Alvim-Ferraz MC, Morais S, Pereira MC (2011a) Air pollution from traffic emissions in Oporto, Portugal: Health and environmental implications. Microchem J99(1):51-59

Slezakova K, Pires JCM, Martins FG, Pereira MC, Alvim-Ferraz MC (2011b) Identification of tobacco smoke components in indoor breathable particles by SEM-EDS. Atmos Environ 45:863872

Slezakova K, Alvim-Ferraz MC, Pereira MC (2012) Elemental characterization of indoor breathable particles at a Portuguese urban hospital. J Toxicol Environ Health A 75:909-919

Song F, Gao Y (2011) Size distributions of trace elements associated with ambient particular matter in the affinity of a major highway in the New Jersey - New York metropolitan area. Atmos Environ 45:6714-6723

Sulaiman N, Abdullah M, Lo Lo Poh Chieu P (2005) Concentration and composition of PM10 in outdoor and indoor air in industrial area of Balakong Selangor, Malaysia. Sains Malays 34:43-47

Sureda X, Fu M, López MJ, Martínez-Sánchez JM, Carabasa E, Saltó E, Martínez C, Nebot M, Fernández E (2010) Second-hand smoke in hospitals in Catalonia (2009): a cross-sectional study measuring PM2.5 and vapor-phase nicotine. Environ Res 110:750-755

Susaya J, Kim K, Ahn J, Jung M, Kang C (2010) BBQ charcoal combustion as an important source of trace metal exposure to humans. J Hazard Mater 176:932-937

Talon D (1999) The role of the hospital environment in the epidemiology of multi-resistant bacteria. Hosp Infect 43(1):13-17

Taner S, Pekey B, Pekey H (2013) Fine particulate matter in the indoor air of barbeque restaurants: Elemental compositions, sources and health risks. Sci TotalEnviron454-455:79-87

Tang JW, Noakes CJ, Nielsen PV, Settles GS (2011) Observing and quantifying airflows in the infection control of aerosol and airborne-transmitted diseases: An overview of approaches. J Hosp Infect 77:213-222 
United States Environmental Protection Agency (USEPA) (1989) Risk assessment guidance for superfund, vol I: Human health evaluation manual. EPA/540/1-89/002. Office of Emergency and Remedial Response, Washington, DC

United States Environmental Protection Agency (USEPA) (2011) Exposure factors Handbook: 2011 edition. EPA/600/R-09/052F, Office for Research and Development, Washington, DC

United States Environmental Protection Agency (USEPA)(2013a) Riskbased concentration table. <http://www.epa.gov/reg3hwmd/risk/ human/index.htm>. Accessed 12 January 2013

United States Environment Protection Agency (USEPA) (2013b) Users' guide and background technical document for USEPA regions 9'S preliminary remediation goals. http://www.epa.gov/region9/ superfund/prg/files/04usersguide.pdf. Accessed 7 Jan 2013

Valavanidis A, Fiotakis K, Vlachogianni T (2008) Airborne particulate matter and human health: Toxicological assessment and importance of size and composition of particles for oxidative damage and carcinogenic mechanisms. J Environ Sci Health C Environ Carcinog Ecotoxicol Rev 26:339-362

Verma N, Taneja A (2011) Particulate matter exposure in hospitals of urban city located in northern central India. Indian JEnviron Prot 31: 627-634

Vieira C, Morais S, Ramos S, Delerue-Matos C, Oliveira MBPP (2011) Mercury, cadmium, lead and arsenic levels in three pelagic fish species from the Atlantic Ocean: Intra- and inter-specific variability and human health risks for consumption. Food Chem Toxicol 49:923-932
Wan G-H, Chung F-F, Tang C-S (2011) Long-term surveillance of air quality in medical center operating rooms. Am J InfectControl 39:302-308

Wang X, Bi X, Sheng G, Fu J (2006a) Hospital indoor PM10/PM2.5 and associated trace elements in Guangzhou, China. Sci Total Environ 366:124-135

Wang X, Bi X, Chen D, Sheng G, Fu J (2006b) Hospital indoor respirable particles and carbonaceous composition. Build Environ 41:9921000

Wang Y-T, Chiu J-C, Hsu Y-C, Wu T-N, Shen Y-H, Wen S-B (2011) Investigation on indoor air quality of public sites in Tainan area. Adv Mat Res 255-260:1413-1417

World Health Organization (WHO) (2000) WHO Air quality guidelines for Europe, 2nd edition. WHO Regional Publications, European Series No. 91, Denmark

World Health Organization (WHO) (2006) Air quality guidelines, global update 2005. World Health Organization, Geneva

World Health Organization (WHO) (2007) Health risks of heavy metals fromlong-range transboundary airpollution. WHORegionalOffice for Europe, Copenhagen

World Health Organization (WHO) (2010) WHO guidelines for indoor air quality: selected pollutants. WHO Regional Office for Europe, Copenhagen

Yurtseven E, Erdogan MS, Ulus T, Sahin UA, Onat B, Erginoz E, Vehid S, Koksal S (2012) An assessment of indoor PM2.5 concentrations at a medical faculty in Istanbul, Turkey. Environ Protect Eng 38: $115-127$ 